University of Nebraska - Lincoln

DigitalCommons@University of Nebraska - Lincoln

Publications from USDA-ARS / UNL Faculty

U.S. Department of Agriculture: Agricultural

Research Service, Lincoln, Nebraska

2001

Genetic Modification of Herbaceous Plants for Feed and Fuel

Kenneth P. Vogel

University of Nebraska-Lincoln, kvogel1@unl.edu

Hans-Joachim G. Jung

USDA-ARS, jungx002@tc.umn.edu

Follow this and additional works at: https://digitalcommons.unl.edu/usdaarsfacpub

Vogel, Kenneth P. and Jung, Hans-Joachim G., "Genetic Modification of Herbaceous Plants for Feed and Fuel" (2001). Publications from USDA-ARS / UNL Faculty. 1915.

https://digitalcommons.unl.edu/usdaarsfacpub/1915

This Article is brought to you for free and open access by the U.S. Department of Agriculture: Agricultural Research Service, Lincoln, Nebraska at DigitalCommons@University of Nebraska - Lincoln. It has been accepted for inclusion in Publications from USDA-ARS / UNL Faculty by an authorized administrator of DigitalCommons@University of Nebraska - Lincoln. 


\title{
Genetic Modification of Herbaceous Plants for Feed and Fuel
}

\author{
Kenneth P. Vogel \\ USDA-ARS, 344 Keim Hall, University of Nebraska. P.O. Box 830937, Lincoln, NE 68583-0937. \\ Email:kpv@unlserve.unl.edu.
}

\author{
Hans-Joachim G. Jung \\ USDA-ARS, 411 Borlaug Hall, 1991 Upper Buford Circle, University of Minnesota, St. Paul, MN. 55108. Email: \\ jungx002@tc.umn.edu.
}

Referee: Dr. E. Charles Brummer, Forage Breeding and Genetics, 1204 Agromonomy, lowa State University, Ames, IA 50011

\begin{abstract}
Much of the research on the genetic modification of herbaceous plant cell walls has been conducted to improve the utilization of forages by ruminant livestock. The rumen of these animals is basically an anaerobic fermentation vat in which the microflora break down the complex polysaccharides of plant cell walls into simpler compounds that can be further digested and absorbed by the mammalian digestive system. Research on improving the forage digestibility of switchgrass, Panicum virgatum L., and other herbaceous species has demonstrated that genetic improvements can be made in forage quality that can have significant economic value. To meet future energy needs, herbaceous biomass will need to be converted into a liquid fuel, probably ethanol, via conversion technologies still under development. If feedstock quality can be genetically improved, the economics and efficiency of the conversion processes could be significantly enhanced. Improving an agricultural product for improved end product use via genetic modification requires knowledge of desired quality attributes, the relative economic value of the quality parameters in relation to yield, genetic variation for the desired traits, or for molecular breeding, knowledge of genes to suppress or add, and knowledge of any associated negative consequences of genetic manipulation. Because conversion technology is still under development, desirable plant feedstock characteristics have not been completely delineated. Some traits such as cellulose and lignin concentration will undoubtably be important. Once traits that affect biomass feedstock conversion are identified, it will be highly feasible to genetically modify the feedstock quality of herbaceous plants using both conventional and molecular breeding techniques. The use of molecular markers and transformation technology will greatly enhance the capability of breeders to modify the morphologic structure and cell walls of herbaceous species. It will be necessary to monitor gene flow to remnant wild populations of biomass plants and have strategies available to curtail gene flow if it becomes a potential problem. It will also be necessary to monitor plant survival and longterm productivity as affected by these genetic changes to herbaceous species.
\end{abstract}

\section{INTRODUCTION}

Much of the research on the genetic modification of herbaceous plant cell walls has been conducted to improve the utilization of forages by ruminant livestock, including cattle and sheep. The rumen of these animals is basically an anaerobic fermentation vat in which microflora break down the complex polysaccharides of plant cell walls into simpler compounds that can be digested further and absorbed by other organs in the digestive system. Ruminants have energy require- ments for maintenance and rumen capacity limits the amount of forage that can be digested in a day. Consequently, small improvements in the conversion or digestibility of forages in ruminants can significantly increase the digestible energy intake of animals that can lead to economically significant exponential increases in per animal milk or meat production, as illustrated in Figure 1 (from Vogel and Moore, 1993). Averaged over 10 cultivars of both cool- and warm-season grasses, a $1 \%$ increase in vitro dry matter digestibility (IVDMD) resulted in a $3.2 \%$ increase in daily

0735-2689/01/\$.50

(C) 2001 by CRC Press LLC 


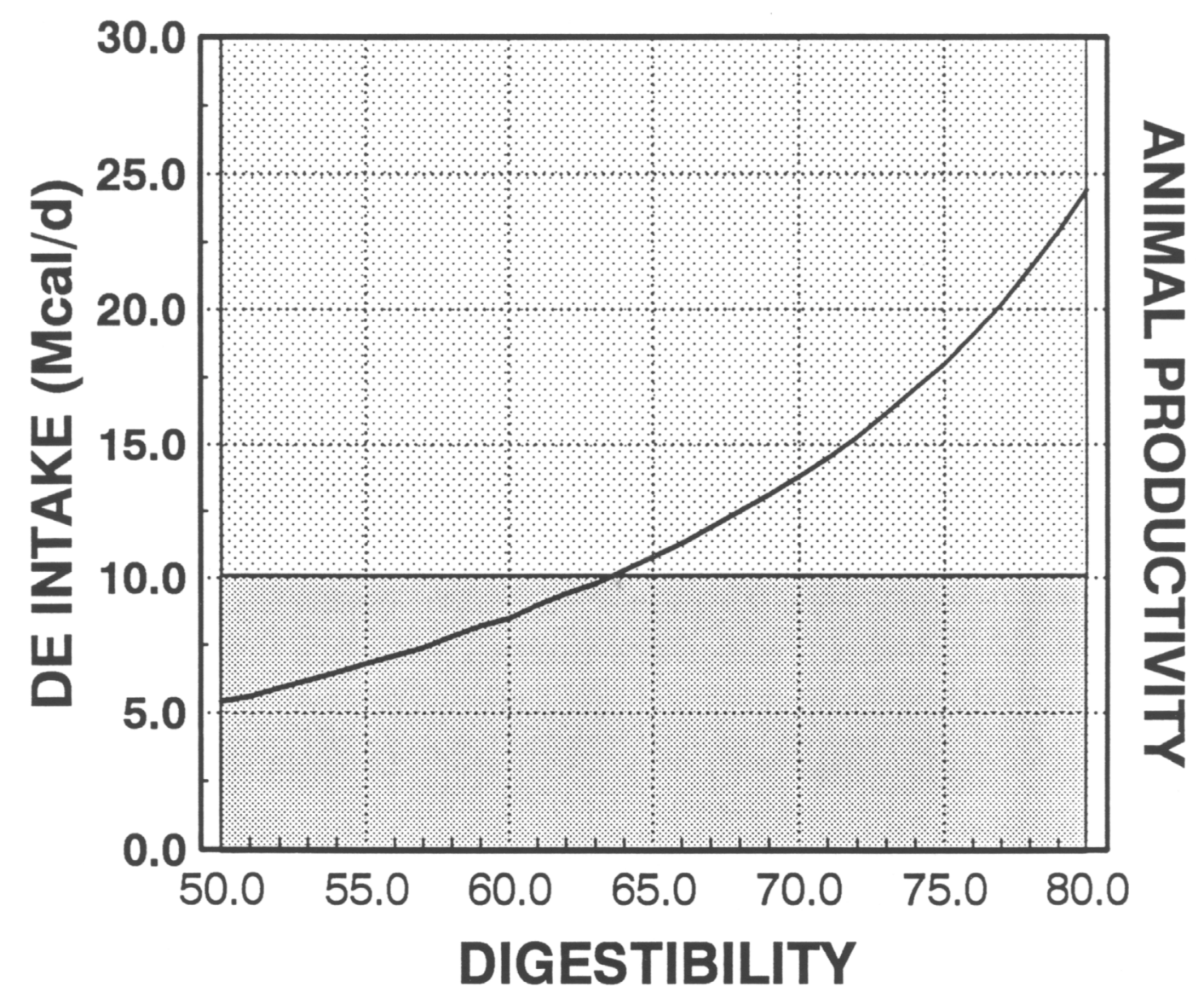

FIGURE 1. Animal productivity increases exponentially with improvements in forage digestibility. Digestible energy (DE) intake values are for a $300-\mathrm{kg}$ beef steer. The darker shaded area represents maintance requirements (Vogel and Moore, 1993).

gains (Casler and Vogel, 1999). In regions that have the forage production potential of the Midwestern Region of the U.S., a percentage unit increase in IVDMD in small plot trials has a potential economic value of $\$ 25 /$ ha to livestock producers when grown in pastures (Vogel and Sleper, 1994).

Switchgrass (Panicum virgatum L.), a perennial warm-season grass native to the prairies of North America, has been identified by the U.S. Department of Energy (DOE) as its main species of emphasis for development into a herbaceous biomass fuel crop. Switchgrass biomass feedstock will be a raw agricultural commodity that will be need to be converted into a liquid fuel, probably ethanol, via conversion technology still under development. Depending on the conversion technology that is used, there will be byproducts that may have positive or negative economic value. If feedstock quality can be ge- netically modified, the efficiency of the conversion process could be enhanced resulting in more desirable primary or secondary products and reduced undesired byproducts. Improvements in biomass feedstock quality also may improve the efficiency of feedstock conversion plants. In contrast to forages, the economic value of any change in cell wall composition for biomass conversion is unknown. The objective of this review is to evaluate the feasibility of making substantial genetic improvments in feed and biomass feedstock quality of switchgrass and other herbaceous plants by classic selection and breeding and/or genetic transformation. The report focuses on switchgrass but will be applicable to other herbaceous species. Areas that are covered in this report include:

A. Composition, development, and distribution of cell walls in herbaceous plants 
B. Developmental and environmental factors that affect herbaceous biomass quality

C. Modification of biomass quality via traditional plant breeding methods

D. Utilization of genetic markers to enhance plant breeding effectiveness

E. Modifying feed and biomass composition using plant transformation technologies

F. Environment and ecosystem constraints on the use of genetically modified organisms

E . Feed and feedstock quality assessment in breeding, management, and production research

In most industrial applications, the conversion technology that will be used to convert a raw agricultural product into a finished product and the feedstock parameters that need to be modified to improve conversion efficiency are known before a plant breeding effort is initiated. Because conversion technology is still under development and desirable plant feedstock characteristics have not been delineated, this report discusses potentially useful quality parameters that are likely to be amenable to genetic modification.

\section{A. Composition, Development, and Distribution of Cell Walls in Herbaceous Plants}

The energy in herbaceous plant biomass is largely in plant cell walls. Cell walls comprise 40 to $80 \%$ of the biomass in herbaceous plants, depending on species and maturity of the plant material. Cellulose, hemicellulose, and pectin are the polysaccharide components of plant cell walls. Cellulose is composed of $\beta 1,4$ linked glucose. In contrast, hemicellulose and pectin are comprised of mixtures of both hexose and pentose sugars with a variety of linkage types (Hatfield, 1993). Lignin, a phenolic polymer, is the other major constituent in walls. Smaller amounts of protein and minerals are also present. Grasses contain 1 to $2 \%$ hydroxycinnamic acids (ferulate and $p$-coumarate) in their cell walls and ferulates cross-link arabinoxylan to lignin (Jung and Deetz, 1993; Ralph et al., 1998a). As plants mature, wall composition shifts from moderate levels of protein $(\sim 10 \%)$ and almost no lignin to very low concentrations of protein and substantial amounts of lignin (20 to $30 \%$ ). Cellulose typically represents $\sim 50 \%$ of the polysaccharide fraction in the cell wall of herbaceous plants. In grasses, the remaining polysaccharide is primarily hemicellulose with only small $(\sim 5 \%)$ amounts of pectin. Grass hemicellulose consists mostly of arabinoglucuronoxylans. In legumes and other dicotyledons, pectin accounts for 30 to $40 \%$ of the noncellulosic polysaccharides, and the hemicellulose consists primarily of xyloglucans.

It should be noted that much of the literature on cell wall concentration and composition for agriculturally important grass and legume species is inaccurate because of the method of analysis typically employed. The compositional data presented earlier are based on methods that measure total cell wall polysaccharides by acid hydrolysis and chromatographic determination of component neutral sugars, plus a spectrophotometric assay for acidic sugars (e.g., Theander et al., 1995). Lignin concentration is based on a gravimetric determination of the nonhydrolyzable residue (Klason lignin). More typically, the detergent system of analysis (Van Soest, 1994) is used for analysis of grasses and legumes by agricultural scientists. Most of the pectin in the cell wall is lost by solubilization during the first step of the detergent system where neutral detergent fiber (NDF) is isolated. The relative amounts of cellulose, hemicellulose, and lignin are calculated by difference from sequential determinations of NDF, acid detergent fiber (ADF), acid detergent lignin (ADL), and ash. Because of incomplete solubilization of protein and hemicellulose by the NDF and ADF steps, respectively, calculation of hemicellulose and cellulose are biased by contaminants (Morrison, 1980). The net result is that $\mathrm{NDF}$ is a reasonably accurate estimate of total cell wall for grasses because of the low concentration of pectin in grasses, but NDF significantly underestimates cell wall concentration in legumes because of their higher pectin levels. Because of contamination problems, cellulose and hemicellulose estimates from the detergent system should be viewed with caution. 
However, the greater error in the detergent system is that ADL underestimates lignin concentration by a factor of two to four times in grasses and 30 to $100 \%$ in legumes, compared with the Klason lignin method. A series of studies (Kondo et al., 1987; Hatfield et al., 1994; Lowry et al., 1994; Jung et al., 1999b) have established that Klason lignin is the more accurate method for quantifying lignin in herbaceous plants. The use of ADL has resulted in substantial overestimates of polysaccharide content in grasses and other herbaceous plants due to the underestimation of the lignin content. For example, from the data of Hatfield et al. (1994) it can be calculated that using ADL, compared with Klason lignin, for the determination of the lignin concentration overestimated the cell wall polysaccharide content of switchgrass stems by $\sim 12 \%$. While ADL and Klason lignin concentration estimates are correlated ( $\mathrm{r}=0.75$, Jung et al., 1997a), we have not attempted to correct the ADL values drawn from literature sources cited in this review.

While herbaceous biomass increases in cell wall concentration and lignin proportion of the wall during plant maturation, these changes do not occur in all tissues. In alfalfa (Medicago sativa $\mathrm{L}$.) there are several tissues (epidermis, collenchyma, chlorenchyma, secondary phloem, cambium, and protoxylem parenchyma) that never lignify (Engels and Jung, 1998); however, some of these tissues (epidermis and collenchyma) do develop thick cell walls during the maturation process. In the case of alfalfa collenchyma tissue, these thick mature cell walls are extremely rich in pectin. The majority of the cell wall material in legume stems is in the xylem tissue that develops thick walls rich in cellulose, hemicellulose, and lignin. During cambial growth in dicots, this xylem tissue becomes an ever-increasing proportion of the stem with maturity (Engels and Jung, 1998). Alfalfa has another unique tissue, primary phloem, that develops a very thick secondary wall that is extremely rich in cellulose, but contains no lignin (Engels and Jung, 1998). If legumes could be genetically modified to alter the relative proportions of the tissues comprising the stem, then cell-wall composition could be dramatically shifted.

In contrast to legumes such as alfalfa, grass tissues do not differ so dramatically in cell wall composition. While the phloem and mesophyll tissue in grasses remains nonlignified, all other tissues lignify to some extent (Wilson, 1993). Parenchyma bundle sheath cells are a specialized tissue in $\mathrm{C} 4$ grasses that thicken and lignify to varying extent depending on the species. There are no nonlignified, pectin-rich tissues in grasses similar to those found in legumes. The best data available for cell wall composition of grass tissues are from sorghum (Sorghum bicolor (L.) Moench) stems (Hatfield et al., 1999). While polysaccharide content and composition of the wall varied among tissues, the greater difference among tissues was in total cell wall concentration. The potential for altering cell wall polysaccharide content of grasses by shifts in tissue proportions appears to be less than in legumes.

While maturity is the single most important determinate of cell wall concentration and composition, other factors do change the amount and characteristics of plant cell walls. Plant morphology has a major impact on cell-wall concentration of forages due to differences between leaves and stems. For grasses such as big bluestem (Andropogon gerardii Vitman) and switchgrass, leaves have somewhat lower NDF concentrations ( $\sim 55$ vs. $75 \%$ ) than stems (Griffin and Jung, 1983; Jung and Vogel, 1992). In a legume such as alfalfa, the leaves have less than half the NDF content of the stems (Jung et al., 1997b). Another difference between grasses and legumes is that cell-wall concentration of grass leaves increases at almost the same rate as in stems (Jung and Vogel, 1992), whereas legume leaves remain relatively constant in their leaf composition while stems deposit large amounts of additional cellwall material with maturity (Kalu and Fick, 1983). The proportion of lignin in the cell walls of legume leaves and stems do not differ (Jung et al., 1997c), but cell walls of grass stems do tend to be more lignified than leaves (Griffin and Jung, 1983; Jung and Vogel, 1992). The selection for a change in leaf-to-stem ratio will have dramatic effects on cell wall concentration of the total herbage of legumes and smaller, but significant, effects on grass cell wall concentration. Compositional changes in the cell wall are relatively small due to plant morphology. 


\section{B. Developmental and Environmental Factors That Affect Herbaceous Biomass Quality}

The morphological development of most forage species is photoperiod sensitive (Nelson and Volenec, 1995). This includes switchgrass, which requires long days followed by short days to flower (Moser and Vogel, 1995). Photoperiod response can be monitored in field research by monitoring the relationship between day-of-the-year (DOY) and physiological maturity. Mitchell et al. (1997) sampled Trailblazer switchgrass and Pawnee big bluestem grown at Mead, NE, in 1990 and 1991 at weekly intervals and staged the plant material for physiological maturity using the Nebraska staging system of Moore et al. (1991). Regression analysis demonstrated that for both species, physiological maturity at harvest was highly dependent on DOY. Growing degree days, which measure accumulated heat or photosynthetic energy, also affect morphological development and can be responsible for year- to-year variation in morphological develeopment of herbaceous plants
(Mitchell et al., 2001; Sanderson and Wolf, (1995). Growing degree days and DOY correlations of morphological development of herbaceous plants are usually highly correlated in temperate climates. In switchgrass as in other grasses, physiological maturity at harvest has an effect on almost all herbage or biomass characteristics that have been analyzed to date. This includes IVDMD, $\mathrm{NDF}$, hemicellulose, lignin and other traits (Table 1, Figure 2) (Jung and Vogel, 1992; Gabrielsen et al., 1990). Genetically modifying a herbaceous species responsiveness to photoperiod could affect its physiological maturity, which would directly effect feed and biomass quality factors. As an example, plants maintained at a vegetative stage of growth likely would be higher in digestibility and lower in lignin content than plants that flowered due to response to photoperiod. This may be a very suitable approach for annual species but not for perennials. Perennials need to retain photoperiod sensitivity to initiate life cycle processes associated with winter survival.

Photoperiod response of forage or biomass species is under genetic control. Photoperiod re-

TABLE 1. Effect of Maturity on Composition of Leaf and Stem Tissue of Switchgrass V= vegetative, $B=$ Boot, and $H=$ Heading Stages of Maturity

\begin{tabular}{|c|c|c|c|c|c|c|c|}
\hline $\begin{array}{l}\text { Tissue } \\
\text { type and } \\
\text { maturity }\end{array}$ & NDF & $\begin{array}{l}\text { Hemi- } \\
\text { cellulose }\end{array}$ & Cellulose & $\begin{array}{l}\text { Lignin } \\
\text { (ADL) }\end{array}$ & $\begin{array}{l}\text { Esterifi } \\
\text { p-coumaric } \\
\text { acid }\end{array}$ & $\begin{array}{l}d \\
\text { ferulic } \\
\text { acid }\end{array}$ & $\begin{array}{l}\text { Nitro- } \\
\text { benzene } \\
\text { oxidation } \\
\text { yield }\end{array}$ \\
\hline & $\begin{array}{l}\mathrm{g} \mathrm{kg}^{-1} \\
\mathrm{DM}\end{array}$ & \multicolumn{3}{|c|}{----- $\mathrm{g} \mathrm{kg}^{-1}$ NDF } & \multicolumn{2}{|c|}{----g kg-1 NDF-- } & $\begin{array}{l}\mathrm{g} \mathrm{kg}^{-1} \\
\mathrm{ADL}\end{array}$ \\
\hline \multicolumn{8}{|l|}{ Leaf } \\
\hline V & 614 & 495 & 455 & 40 & 4.05 & 4.53 & 78 \\
\hline B & 641 & 496 & 450 & 42 & 4.06 & 4.73 & 77 \\
\hline $\mathrm{H}$ & 682 & 493 & 436 & 54 & 3.63 & 3.82 & 46 \\
\hline \multicolumn{8}{|l|}{ Stem } \\
\hline V & 657 & 467 & 481 & 48 & 7.31 & 5.28 & 144 \\
\hline $\mathrm{B}$ & 723 & 417 & 510 & 75 & 9.58 & 4.38 & 106 \\
\hline $\mathrm{H}$ & 742 & 421 & 495 & 86 & 9.61 & 4.13 & 66 \\
\hline
\end{tabular}

From Jung and Vogel, 1992 


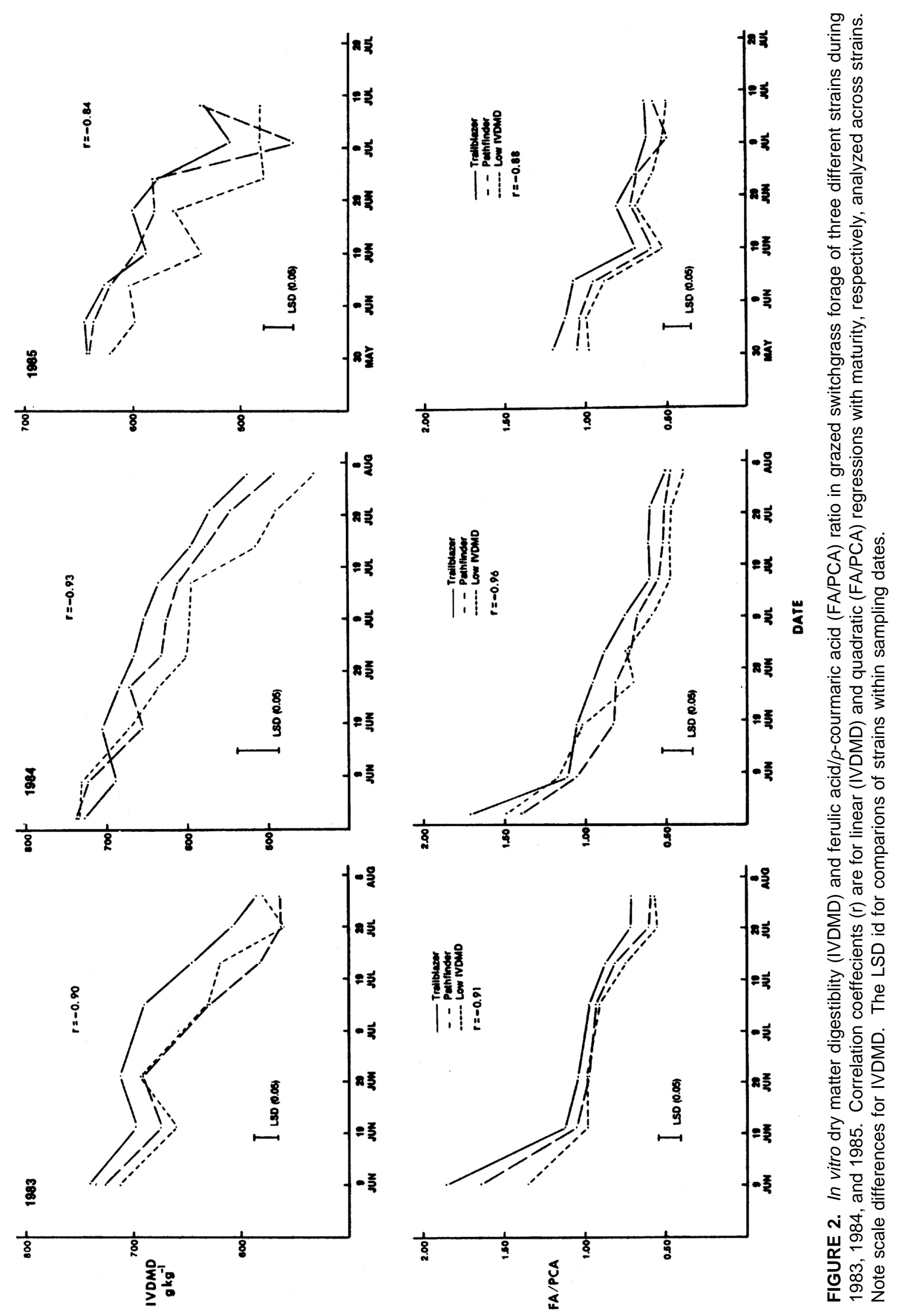


quirements for flowering and fall senescence differ depending upon latitude of origin of the plant germplasm and are among the primarily factors determining cultivar adaptation (Moser and Vogel, 1995). When genetic populations or cultivars of North American prairie species such as switchgrass, big bluestem (Andropogon gerardii Vitman), and indiangrass (Sorghastrum nutans (L.) Nash) are grown north of their area of origin, they are exposed to longer than normal photoperiods for a give date because of latitude. As a result they stay vegetative longer and often produce more biomass than populations or cultivars originating in the evaluation environment (Cornelius and Johnston, 1941; McMillian, 1959, 1965; Newell, 1968). Populations or cultivars originating from northern latitudes are exposed to a shorter than normal photoperiod when grown in southern latitudes and they will flower early and produce less biomass than in their latitude of origin. The photoperiod response also appears to influence winter survival. If moved too far north, populations originating from southern latitudes will stay vegetative too late in the fall and will not survive the winters. A simple and reliable method of breeding for increased biomass yield for photoperiod sensitive species such as switchgrass is to use genetic populations of southern origin in the breeding program. The distance that genetic populations can be moved north of their area of origin varies with species and populations but a general rule is about $500 \mathrm{~km}$ (Vogel and Moser, 1995).

In addition to photoperiod, morphological development also can be affected by other climate-related factors, including temperature and water stress (Nelson and Volenec, 1995). Environmental growth conditions can influence cell wall concentration and, to a lesser extent, composition. Buxton and Fales (1994) and Buxton and Casler (1993) have reviewed the impact of plant growth environment on cell wall concentration and composition. Temperature is the environmental factor that most strongly effects plant cell walls, with high temperatures causing an increased rate of reproductive maturation. A major impact of more rapid reproductive development is a reduction in leaf-to-stem ratio. High temperatures also result in higher cell wall concentration, with increases occurring in both the polysaccharide and lignin fractions (Buxton and Fales, 1994). Switchgrass leaves and stems had higher lignin and lower NDF digestibility when grown at $32^{\circ} \mathrm{C}$ in comparison to switchgrass grown at $22^{\circ} \mathrm{C}$ (Wilson et al., 1991). Moisture stress of alfalfa due to drought reduces cell wall deposition relative to the normal accumulation that occurs with maturation while reproductive development proceeds, but composition of the wall is not affected (Halim et al., 1989; Deetz et al., 1994). Nitrogen fertilization increases total plant growth rate but does not alter cell wall development (Buxton and Fales, 1994).

In the studies that have been conducted to date, genetic differences in forage quality parameters have been stable over environments, thta is, genotype $\mathrm{x}$ environment interactions have been small and usually nonsignificant (Vogel and Sleper, 1994; Casler and Vogel, 1999). Environment as described above does affect biomass quality factors such as IVDMD, but the genetic differences remain consistent over environment. This has been demonstrated in several studies with switchgrass (Hopkins et al., 1993, 1995a,1995b; Gabrielsen et al., 1990; Vogel et al.1981) and is illustrated in Figure 2 (from Gabrielsen et al., 1990). As illustrated in Figure 2, the primary factor affecting both IVDMD and the FA/PCA ratio is plant maturation. There are year-to-year differences in the forage quality parameters (note difference in scale for IVDMD for 1985 vs 1983 and 1984 in Figure 2) but the differences among strains remains consistent over years and within years. Environmental conditions and management practices can interact to significantly affect dry matter losses and detrimental changes in quality of forage during storage (Collins and Moore, 1995). Improper storage conditions can reduce IVDMD by over 10 percentage units and increase ADL by over 5 percentage units (Collins and Moore, 1995).

\section{Modification of Biomass Quality via Traditional Plant Breeding Methods.}

Conventional plant breeding involves manipulating the alleles of a species so that desired alle- 
les are packaged together in the same plant and as many deleterious genes as possible are excluded. Improvements in biomass quality that can be made in species such as switchgrass is dependent on the genetic variability for the traits of interest in the species, the heritability of the traits, the breeder's ability to identify genetically superior plants, the intensity of selection, and the efficiency of the breeding procedure. Heritability is the ratio of the genetic variation for a trait divided by the phenotypic variation.

The two main components of the plant breeding process are selection and hybridization. The selection of the plants to be mated is the critical component of the conventional breeding process because breeders evaluate phenotypes in order to select superior genotypes. The other component, hybridization or mating, can usually be done in a routine manner, although for some species the procedures are tedious and require a high degree of skill (Fehr and Hadley, 1980; Martinez-Reyna and Vogel, 1998). Breeding systems have been developed and continue to be developed that can be used to improve virtually all forage species. Recent reviews have described the relative theoretical and practical efficiencies of these systems (Sleper, 1987; Vogel and Pedersen, 1993). Forage breeders have an array of breeding procedures that they can use to improve forage species. The critical problem involved in improving forage or biomass quality is having rapid, reliable, and relatively inexpensive quality assays and relative estimates of economic value of quality traits for biomass conversion.

A few basic equations can be used to express many of the concepts involved in plant breeding (Allard, 1964; Falconer, 1981). Assuming selection is conducted on an individual plant basis, the heritability estimate $\left(\mathrm{h}_{\mathrm{x}}{ }^{2}\right)$ for a trait " $\mathrm{x}$ " (Eq. 1) is the ratio of the additive genetic variation $\left(\sigma_{\mathrm{ax}}{ }^{2}\right)$ for that trait divided by the phenotypic variance $\left(\sigma_{\mathrm{P}}{ }^{2}\right)$ (Falconer, 1981). Except for a few forage species for which it is possible to produce commercial $F_{1}$ hybrids, forage breeders have to utilize additive genetic variation. Breeding progress using additive genetic variation is due to the "additive" effects of increasing the frequency of desirable genes in plants or plant populations. Additive genetic variation is used as the numerator in Eq.
1 to provide an estimate of heritability in the narrow sense. Plant breeders and geneticists use various mating and evaluation strategies to obtain estimates of the additive genetic and phenotypic variance (Hallauer and Miranda, 1981). Narrow sense heritability estimates are used to predict gain from selection and also provide an estimate of the proportion of the total variation for a trait that can be attributable to genetic differences among individuals or families. Heritability estimates can range from 1.0 for a trait such as eye color that is not affected by environment to less than 0.10 for traits that are highly influenced by environment variables.

$$
\begin{gathered}
\mathrm{h}_{\mathrm{x}}^{2}=\sigma_{\mathrm{ax}}^{2} / \sigma_{\mathrm{P}}^{2} \\
\mathrm{G}_{\mathrm{x}}=\mathrm{i} \mathrm{h}_{\mathrm{x}} \sigma_{\mathrm{ax}} \\
\mathrm{CG}_{\mathrm{x}}=\mathrm{i} \mathrm{h}_{\mathrm{y}} \mathrm{r}_{\mathrm{xy}} \sigma_{\mathrm{ax}}
\end{gathered}
$$

Gain from selection for a trait is the gain that is achieved by selecting individuals for that trait and intermating the selected plants to produce their progeny. The mean difference between the progeny of selected and unselected plants is the realized gain from selection. The expected or predicted gain from selection $\left(G_{x}\right)$ for trait " $x$ " is the product of the standardized selection differential (i), the square root of the heritability of the trait $\left(\mathrm{h}_{\mathrm{x}}\right)$, and the square root of the additive genetic variation $\left(\sigma_{\mathrm{ax}}\right)$ (Eq. 2). The standardized selection differential is simply the proportion of selected plants expressed in units of standard deviations from the mean. The genetic gain that can be achieved in a single breeding cycle is dependent on the relative magnitude of the factors in Eq. 2.

The selection for one trait can have an effect on another trait if the traits are genetically correlated. The expected correlated response $\left(\mathrm{CG}_{\mathrm{x}}\right)$ for trait " $x$ " if selection is practiced for trait " $y$ " is given in Eq. 3. The genetic correlation is $\left(\mathrm{r}_{\mathrm{xy}}\right)$. If the genetic correlation is large and the heritability for trait $y$ is also large, then substantial gains from selection can be achieved for a particular trait by indirect selection for the correlated trait. Indirect 
selection can be as effective as direct selection if $h_{y}$ is $25 \%$ larger than $h_{x}$ and the genetic correlation is 0.8 or larger. Correlated responses to selection can be important in breeding for improved digestibility in terms of selection criteria. Markerassisted selection can be extremely effective if the correlation between the molecular marker (y) and the phenotypic trait ( $\mathrm{x}$ ) is large because heritability for a molecular marker (trait y) is usually 1.0 as is the additive genetic variation (see following section on marker assisted selection). When selection is practiced for a single traits such as high yield, it can have a negative effect on other traits such as lignin if the genetic correlation between yield and lignin is negative.

Plant breeders are often interested in simultaneously improving several traits. The three basic methods for improvement of more than one trait by breeding are selection indexes, independent culling, and tandem selection (Baker, 1986; Wricke and Weber, 1986). In tandem selection, a trait is selected until it reaches a targeted level and then breeding work is initiated on the next trait. Tandem selection is basically a trait by trait improvement method. With independent culling, minimum thresholds are established for each trait and only individuals that have all traits of interest above the culling level for each specific trait are selected for mating. With selection indexes, a single score is developed which is a summation of merits and demerits of an individual or family for the desired traits. It allows economic weights to be assigned to each trait of interest. Limited genetic information about the selection populations is needed for tandem selection and for independent culling. Selection indexes, however, require information on the genetic variances and co-variances of the traits of interest and also relative economic weights (Baker, 1986).

A selection index can be expressed as:

$$
\mathrm{I}=\mathrm{b}_{1} \mathrm{P}_{1}+\ldots \ldots \ldots+\mathrm{b}_{\mathrm{i}} \mathrm{P}_{\mathrm{i}} \ldots \ldots \ldots+\mathrm{b}_{\mathrm{n}} \mathrm{P}_{\mathrm{n}}
$$

where $P_{n}$ represents the observed phenotypic value of the nth trait and $b_{n}$ is the weight assigned to the trait in the selection index. The index value is an estimator of the genotypic worth or value of the genotype. To obtain the " $b$ " values, a set of simultaneous equations must be solved that contain the phenotypic and genetic variances and co-variances of each trait and relative economic weights (Baker, 1986). The phenotypic and genetic variances and co-variances can be obtained from structured genetic studies. The economic weights have to be developed from economic analysis in which the relative value of specific traits to the per unit value of the final product is determined.

Developing relative economic weights for traits can range from being relatively straightforward and simple to very complex and difficult. If the traits of interest are for the same aspect of a product such as oil and protein content of soybeans, then the relative value of oil and protein in the marketplace can serve as the economic weights. It becomes more complex if two or more traits relate to different aspects of the same product. For example, increasing biomass yield of switchgrass is desirable because it can reduce the per ton production cost of feedstock. Decreasing lignin content may be desirable for increasing conversion efficiency. However, genetically decreasing lignin content may result in decreased biomass yields. This has occurred in switchgrass as the result of selection for high IVDMD (Table 4; Figure 3). The question that has to be answered is what are the relative economic values of yield vs. lignin or other quality trait. This question needs to be answered not only for the genetic improvement but also for the purchase and utilization of feedstocks at the conversion plant.

The stability of a trait over environments is important because it will influence the area of adaptation of an improved cultivar. Breeders can obtain estimates of the genotype $\mathrm{x}$ environment interactions by growing cultivars or experimental strains in an array of environments. Variance component analyses and regression procedures are used to determine the relative magnitude of genetic, environment, and genotype $\mathrm{x}$ environment interaction $(\mathrm{GxE})$ effects. If genetic effects are significant and $\mathrm{GxE}$ effects are nonsignificant for a specific trait even though environment effects are large, then the trait is stable over environments. If $\mathrm{GxE}$ effects are larger than genotypic effects, it may be necessary for breeders to develop cultivars for specific environments.

Genetic variability for forage quality traits has been found for virtually every species for 


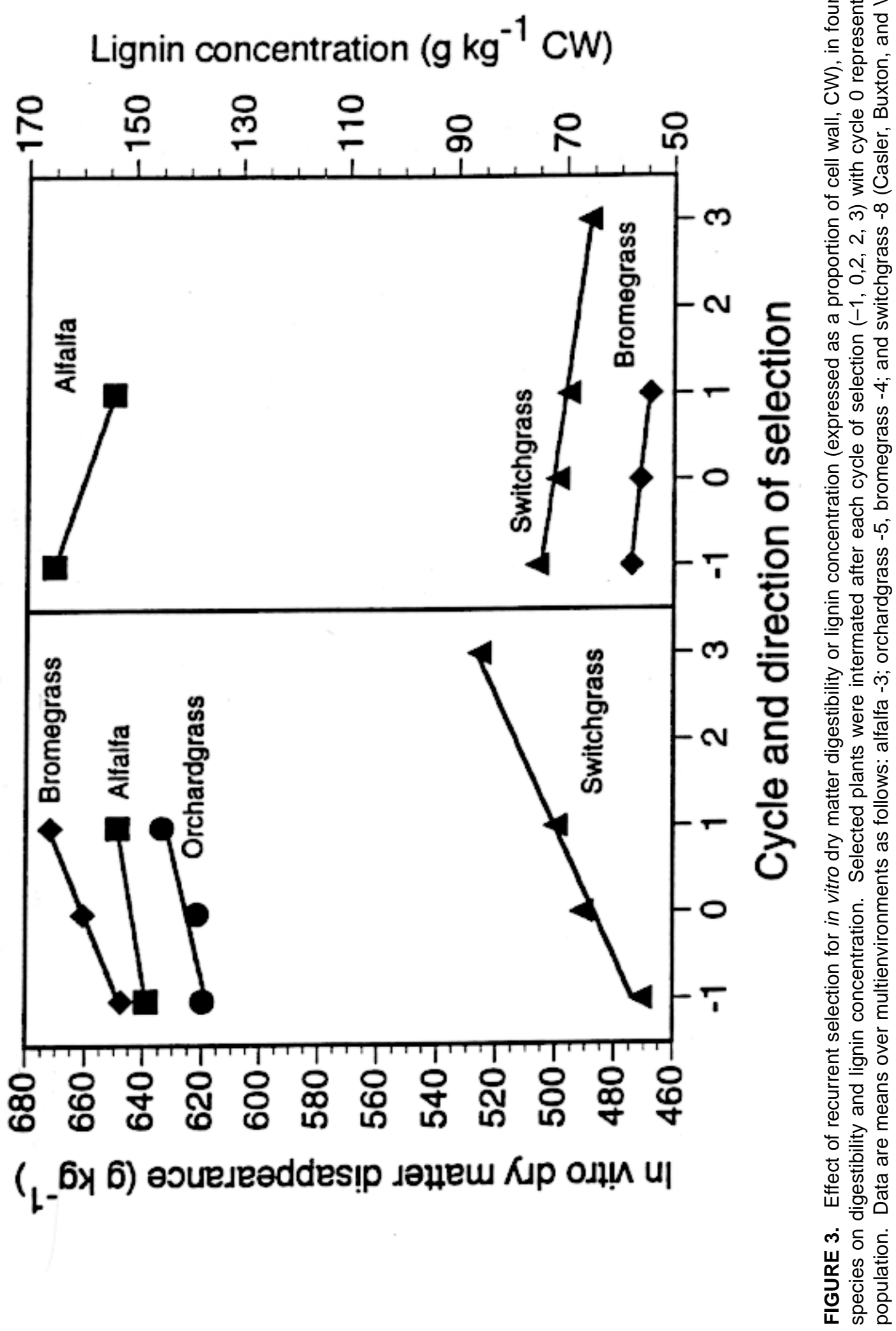


which a well-designed and conducted trial has been completed, including forage digestibility. In most populations of herbaceous plants that have been studied, a range in IVDMD of $100 \mathrm{~g} \mathrm{~kg}^{-1}$ has often been found between individuals of the same population (Casler and Vogel, 1999). Realized heritabilities have been 0.2 to 0.3 , and the rate of genetic progress in breeding for improved IVDMD has ranged from 8 to $45 \mathrm{~g} \mathrm{~kg}^{-1}$ cycle ${ }^{-1}$ (1.3 to $12.1 \%$ cycle $^{-1}$ or 0.7 to $2.5 \%$ year $^{-1}$ ), which is similar to long-term gains for grain yield of cereal crops (Casler and Vogel, 1999). Genetic variation for cell wall monosaccharides, NDF, and ADF in a lowland switchgrass population was evaluated by Godshalk et al. (1988b). Significant genetic variation was found for arabinose, galactose, glucose, xylose, hexose, pentose, and total sugars expressed as $\mathrm{g} \mathrm{kg}^{-1} \mathrm{NDF}$ and for IVDMD, NDF, and ADF. Heritability estimates as determined by parent-progeny regression were greater than 0.5 for all traits (Godshalk et al., 1988b). IVDMD was positively correlated to glucose and hexose sugar concentrations but was negatively correlated to the other monosaccharides.

Switchgrass is one of the principal species on which breeding and genetics research has been conducted to genetically modify herbage or biomass quality. Breeding work to improve the IVDMD of switchgrass has been conducted by co-author Vogel and colleagues for over 20 years, and a series of experiments has been conducted evaluating the breeding progress and associated changes in switchgrass biomass composition. This research also has led to the release of two switchgrass cultivars, Trailblazer and Shawnee, with improved IVDMD (Vogel et al., 1991, 1996).

Breeding for high IVDMD in switchgrass started in an experiment in which a switchgrass population $(\mathrm{EY} \times \mathrm{FF})$ was divergently selected for IVDMD using Restricted Recurrent Phenotypic Selection (RRPS) procedures. The high and low IVDMD populations were evaluated in small trials and in subsequent grazing trials. An additional two cycles of RRPS for high IVDMD have been conducted and were used to produce High IVDMD C2 and C3 strains that have been used in several subsequent studies on the inheritance of IVDMD in switchgrass, the stability of the trait over environments, and the correlated response of agronomic traits, including yield and plant survival and associated forage quality traits. These experiments demonstrated that the IVDMD of switchgrass was improved by breeding using a form of modified mass selection with selected plants polycrossed in isolation (Vogel et al., 1981). It demonstrated that the IVDMD of switchgrass plants sampled at panicle emergence was an excellent predictor of the IVDMD of their progeny in pastures throughout the grazing season (Gabrielsen et al., 1990). A small improvement in IVDMD (3 to 4 percentage units) significantly improved animal performance (17 to $24 \%$ ) as measured by both average daily gains and beef production per hectare in a replicated grazing study conducted for 3 years (Anderson et al., 1988). Differences in animal performance were not due to differences in selectivity but to intrinsic differences in quality (Ward et al., 1989). Additional research demonstrated that changes in forage digestibility were achieved by increasing the extent of cell wall digestibility and not by changing the cell wall to cell solubles ratio or the rate of cell wall digestibility (Moore et al., 1993). The improvement in IVDMD was accompanied by correlated changes in the molar ratio of ferulic acid and p-coumaric acid demonstrating that these components of plant cell walls were heritable and genetically correlated with IVDMD (Gabrielsen et al., 1990). Genetic changes in IVDMD in switchgrass were demonstrated to be stable over a wide range of environments (Hopkins et al., 1995a, 1995b). Estimated and realized heritability for IVDMD averaged over three cycles were 0.40 and 0.31, respectively (Hopkins et al., 1993).

Results from the research on developing switchgrass strains differing in IVDMD also has demonstrated that other herbage traits can be genetically modified. Hopkins et al. (1995a) grew almost all adapted switchgrass cultivars and experimental strains at three Midwest locations (Mead, NE; Ames, IA, and West Lafayette, IN) and harvested biomass yields for 2 years. The $\mathrm{C}(-$ 1), CO, C1 (Trailblazer) and C3 High IVDMD strains were included in these trials. The " $\mathrm{C}$ " is for breeding cycle, the number following the $\mathrm{C}$ denotes the cycle or generations, and a negative sign indicates selection for reduced IVDMD. Averaged over years and locations, the C3 High 
IVDMD strain was $45 \mathrm{~g} \mathrm{~kg}^{-1}$ higher in IVDMD than the $\mathrm{CO}$ strain and also was $8 \mathrm{~g} \mathrm{~kg}^{-1}$ lower in acid detergent lignin (ADL) (Hopkins et al., 1995a). The C3 High IVDMD strain also was $1547 \mathrm{~kg} \mathrm{ha}^{-1}$ lower in biomass yield. In other research, Fritz et al. (1991) demonstrated that there were changes in neutral sugar concentration of cell wall hydrolysates from biomass harvested from progeny of the High and Low IVDMD strains (Table 2).

The selection for high IVDMD in the EY $\mathrm{x}$ FF switchgrass population had correlated genetic affects on other traits. Regression analysis of location means for cycles C(-1) to C3 (Hopkins, 1993; Hopkins et al., 1995a) indicated that for each unit increase $\left(\mathrm{g} \mathrm{kg}^{-1}\right)$ in IVDMD biomass yield decreased by $29 \mathrm{~kg} \mathrm{ha}^{-1}$, crude protein increased by $0.07 \mathrm{~g} \mathrm{~kg}^{-1}$, NDF decreased by $0.21 \mathrm{~g}$ $\mathrm{kg}^{-1}$, and ADL decreased by $0.16 \mathrm{~g} \mathrm{~kg}^{-1}$ (data from co-author K. Vogel). Except for the first cycle of selection that produced the cultivar Trailblazer, each cycle of advanced selection for high IVDMD also reduced digestible dry matter yield $(\mathrm{Mg}$ IVDMD ha-1) and holocellulose yield (cellulose + hemicellulose yield) (Table 4). Because it had biomass yield equivalent to the $\mathrm{C} 0$ and the low IVDMD C-1 population and also had improved IVDMD, Trailblazer gave higher digestible yield than these strains (Table 4).

In 1986, a cycle $4 \mathrm{EY} \times \mathrm{FF}$ High IVDMD RRPS selection nursery was established at Mead, NE. By the early summer of 1987, it was obvious that most of the plants in the nursery had winter killed. Only about 100 plants remained alive. Subsequently, several studies have been conducted to evaluate the effect of breeding for high IVDMD on plant yield and survival of switchgrass. Seed was harvested from all the surviving plants and bulked to produce a High IVDMD C3 WS (winter survivor) population. This strain was included in the multistate trials summarized by Hopkins et al. (1995a). There were no significant differences between the High IVDMD C3 and High IVDMD C3 WS strains for any of the traits evaluated, including IVDMD and ADL. Significant stand loss did not occur in any of these nurseries, but as the plots were solid seeded, the loss of plants could have been compensated by the tillering of the adjacent surviving plants.

Two subsequent space-transplanted studies were initiated to determine the effect of breeding for increased IVDMD or associated cell wall traits on plant yield and survival. Both studies have been summarized recently and are unpublished to date. In a cooperative study, co-author Vogel, M. Casler (Univ. of Wisconsin-Madison), and D. Buxton (USDA-ARS, Ames, IA) evaluated populations of four perennial herbaceous species (switchgrass, orchardgrass [Dactylis glomerata L.], bromegrass [Bromus inermis Leyss.] and alfalfa) that were genetically modified for altered lignin content or associated forage digestibility by conventional plant breeding. The strains were evaluated for fitness in three Midwest USA environments (Mead, NE; Ames, IA; and Madison, WI) for 4 years (Casler et al., 2001). The $\mathrm{EY} \times \mathrm{FF}$ low and high IVDMD switchgrass strains were included in these trials. The results from this research clearly demonstrate that breeding for increased IVDMD or decreased lignin concentration significantly altered both traits over breeding cycles (Figure 3 ). Results also clearly demon-

TABLE 2. Concentrates of Neutral Sugars in Cell Wall Hydrolysates from Ammoniated Switchgrass Herbage Harvested at Heading at Lincoln, NE, As Affected by Genetic Strain Averaged Over Ammoniation Rates of 0, 10, 20, $40 \mathrm{~g} \mathrm{~kg}^{-1}$

\begin{tabular}{|c|c|c|c|c|}
\hline \multirow[t]{2}{*}{ Strain } & Arabinose & Xylose & Galactose & Glucose \\
\hline & \multicolumn{4}{|c|}{ - $\mathrm{g} \mathrm{kg}^{-1}$ hydrolysate - } \\
\hline High IVDMD & 39.5 & 430 & 15.2 & 515 \\
\hline Low IVDMD & 36.3 & 419 & 10.6 & 534 \\
\hline $\mathrm{SE}$ & 3.0 & 8.6 & 1.0 & 3.4 \\
\hline
\end{tabular}

From Fritz et al., 1991. 
TABLE 3. Multiyear Means and Range Values for Herbage Yield, Herbage In Vitro Dry Matter Digestibility, and Survival Percentages for Half-Sib Progeny of EY $\times$ FF High IVDMD C3 Switchgrass Parent Plants and the Check Populations, EY $\times$ FF Low IVDMD C-1, Trailblazer, and EY $\times$ FF Hiah IVDMD C3 Parent Bulk Population

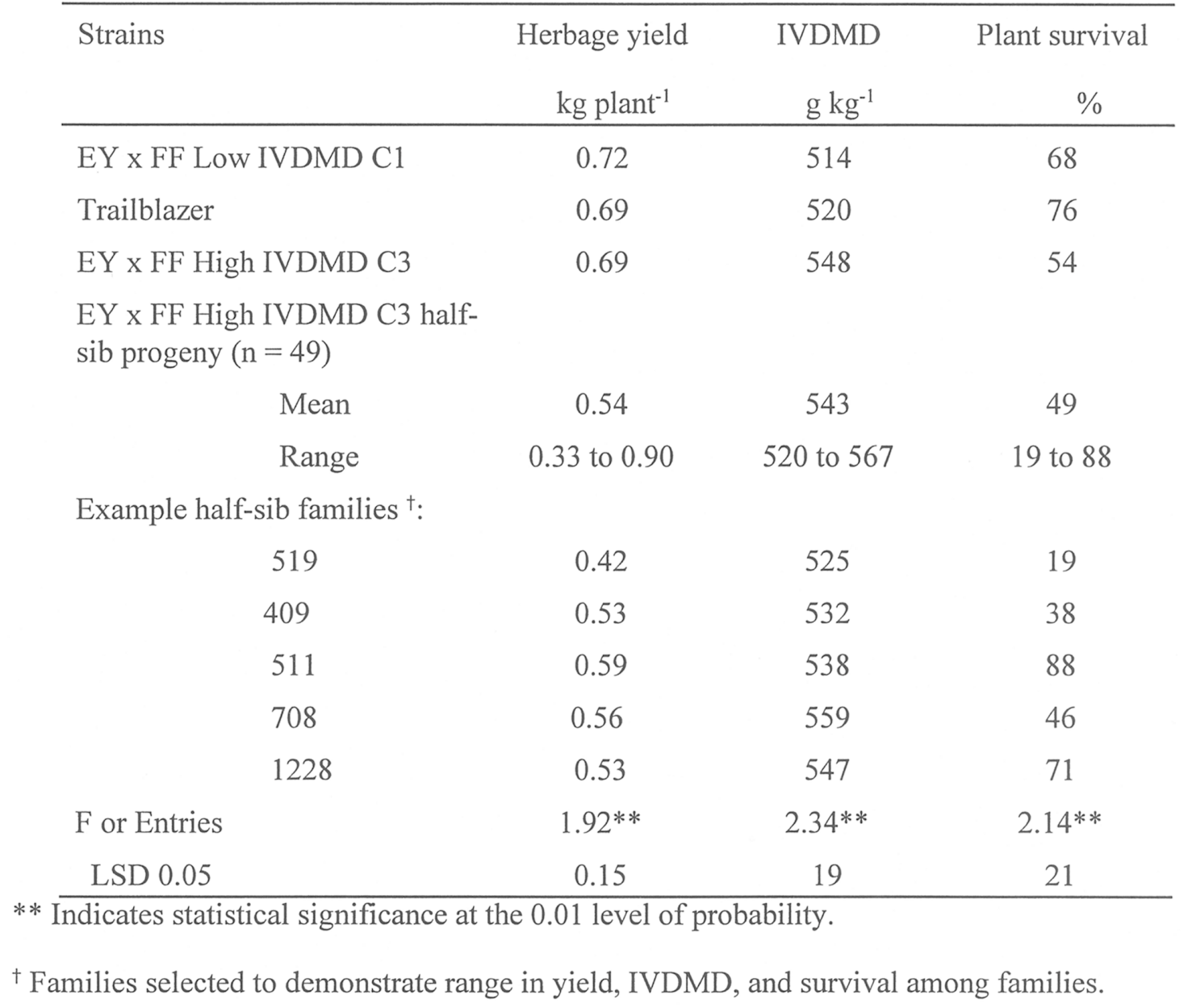

strate that for switchgrass genetically increasing IVDMD or decreasing lignin concentration of the biomass produced populations with significantly reduced plant survival (Figure 4).

Seed was harvested from individual clones of the original High IVDMD C3 parent clones to further evaluate the effect of selection for IVDMD on plant survival. Half-sib families were produced from the seed of the parent clones and were planted into a replicated $(r=3)$ half-sib progeny nursery in 1991 at Mead, NE. The nursery was harvested in 1993 and 1995 for biomass yield after plants had headed, forage samples were collected and analyzed for IVDMD, and number of surviving plants were recorded. $\mathrm{C}-1, \mathrm{C} 1$, and $\mathrm{C} 3$ populations were included as checks. There were significant differences among the families for biomass yield, IVDMD, and plant survival (Table 3).
Among the half-sib families, the correlations for 1993 and 1995 IVDMD and 1995 survival were $r$ $=0.21$ and 0.11 , respectively. The phenotypic correlation between 1993 and 1995 yields and 1995 stands were $r=0.22$ and 0.08 . Breeding for improved IVDMD did reduce winter survival of some families and populations. However, some high IVDMD families had good survival indicating that it should be feasible to continue to breed for high IVDMD, but plant survival over years will need to be monitored.

Lignin is present in all terrestrial higher plants, including herbaceous perennials. It is involved in structural support, antiherbivory, and wound response. Lignin concentration and composition in herbaceous perennials was previously believed to affect evolutionary fitness via its inhibition of herbivory. The switchgrass results clearly dem- 
TABLE 4. Mean Biomass Yield, IVDMD, Digestible Yield, and Holocellulose yield for Switchgrass Strains Grown at Three Midwest Locations and Harvested at Heading that Were Selected for IVDMD or Yield and IVDMD+

\begin{tabular}{|c|c|c|c|c|}
\hline \multirow[t]{2}{*}{ Strain } & \multirow[t]{2}{*}{ IVDMD } & \multicolumn{3}{|c|}{ Yield } \\
\hline & & Biomass & Digestible & Holocellulose \\
\hline & $\mathrm{g} \mathrm{kg}^{-1}$ & $\mathrm{~kg} \mathrm{ha}^{-1}$ & $\mathrm{~kg} \mathrm{ha}^{-1}$ & $\mathrm{~kg} \mathrm{ha}^{-1}$ \\
\hline Cave-in-rock & 434 & 13866 & 6045 & 9550 \\
\hline Shawnee & 446 & 13709 & 6143 & 9441 \\
\hline
\end{tabular}

EY x FF strains:

\begin{tabular}{cllll}
$\mathrm{C}-1$ & 398 & 11904 & 4715 & 8373 \\
$\mathrm{C} 0$ & 427 & 11366 & 4830 & 7959 \\
Trailblazer & 429 & 11851 & 5085 & 8296 \\
$\mathrm{C} 3$ & 473 & 9818 & 4644 & 6859 \\
$\mathrm{SE}^{+}$ & 6 & 367 & 161 & 242 \\
\hline
\end{tabular}

${ }^{+}$Digestible yield= IVDMD\% x Biomass yield; Holocellulose yield = (NDF \% - ADL \%) $\mathrm{x}$

Biomass yield. $\mathrm{SE}=$ standard error of the mean.

onstrate that lignin may also be involved in the plant's ability to survive in the absence of herbivores. These results also indicate that perennial plants genetically engineered with altered lignin concentration or composition for use in livestock, pulp and paper, or bioenergy production will need to be evaluated for fitness prior to use in agriculture. It also points out the need to monitor the effect of changing other plant composition traits on plant survival and biomass yield and the importance of having relative economic value of quality traits.

The direct selection in forages for cell wall components has been conducted less frequently than for IVDMD or NDF concentration. Alfalfa was selected for low and high ADL concentrations (Hill, 1981), but because selection was imposed on total herbage the observed changes in ADL were primarily caused by shifts in leaf-tostem ratio between the low and high ADL selection lines (Kephart et al., 1989, 1990). Selection in corn or maize (Zea mays L.) vegetative tissue for divergent concentrations of ADF resulted in genetic alteration of NDF, ADF, and ADL concentrations for both leaf sheath and stem tissues
(Buendgen et al., 1990). Cellulose concentration was elevated in both leaf sheath and stem tissues of the high ADF line, but hemicellulose concentration was only greater in stem tissue. In another study on maize, Ostrander and Coors (1997) demonstrated that selection for high NDF, ADF, and lignin increased those traits while selection for reduced levels of these components decreased those traits. The selection for improved forage yield and IVDMD has coincidentally generated a bermudagrass (Cynodon dactylon (L.) Pers.) cultivar (Tifton 85) with increased concentration of cellulose (Mandebvu et al., 1999).

The selection for cell wall composition also has been conducted on cool-season grasses. Casler and Jung (1999) attempted to select smooth bromegrass for divergent concentrations of Klason lignin and ferulate cross-linking of lignin to arabinoxylan in young leaves. The selection for Klason lignin was unsuccessful, probably due to large environmental variation, but high and low ferulate cross-linking genotypes were identified. Reduced ferulate mediated cross-linking resulted in improved in vitro NDF digestibility with rumen microrganisms (Casler and Jung, 1999). In 


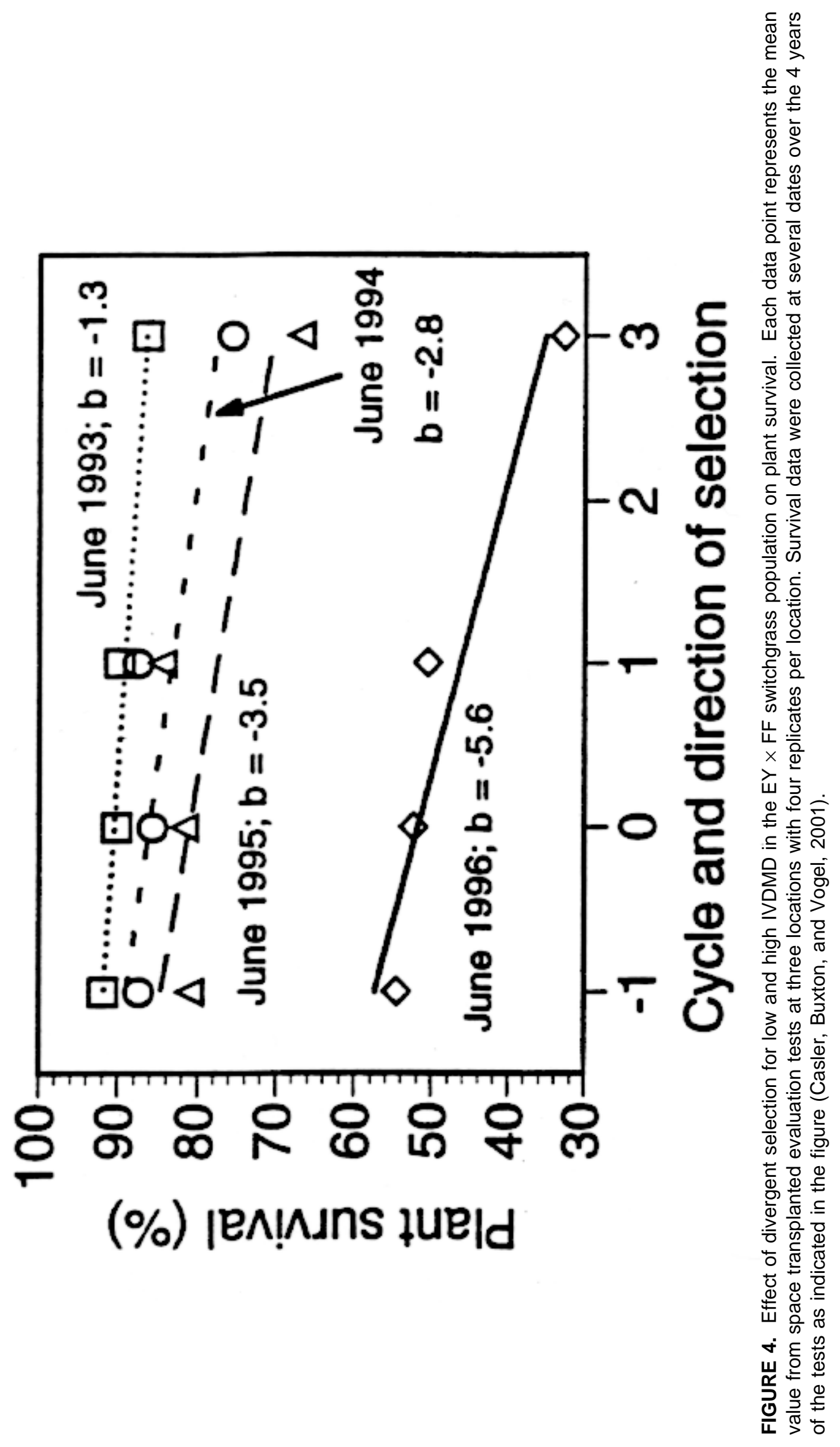


bromegrass, Casler demonstrated that selection for reduced NDF using six different breeding procedures resulted in increased IVDMD (Casler, 1999 a,b,c). When selection for reduced NDF was based on forage collected at heading, correlated responses included a $0.15 \mathrm{Mg} \mathrm{ha}^{-1}$ cycle $^{-1}$ reduction in biomass yield, a $7.5 \%$ per cycle reduction in stem tissue with a concommitant increase in leaf and sheath components and reduced stem and sheath NDF (Casler, 1999a,b,c). Surprenant et al. (1988) used independent culling in reed canarygrass (Phalaris arundinaceae L.) populations in which plants were selected first for high or low NDF and then for high or low yield. Progeny populations produced by the divergent selection and intermating differed significantly for NDF, ADF, and crude protein. Within a fiber selection group, the populations selected for high yield had significantly higher forage yields on a per plant basis than those selected for low yield. Reed canarygrass populations selected for low NDF had lower yields than the base population even when selection included selection for high yield (Surprenant et al., 1988). All the research that has been completed to date on both cool- and warm-season grasses on IVDMD, NDF, ADF, and ADL indicates that these traits are relatively stable over environments (Casler and Vogel, 1999).

The effectiveness of selection indexes in improving yield and IVDMD were evaluated by Godshalk et al. (1988a) in a study in which they compared the results of three different selection indexes for improving yield and IVDMD of switchgrass. Indexes were (1) for increased yield with IVDMD and N (nitrogen concentration) as covariates; (2) increased yield and IVDMD with $\mathrm{N}$ as a covariate; (3) increased IVDMD with yield and $\mathrm{N}$ as covariates. Covariates had a weight of zero. Out of a low-land switchgrass source population of 660 plants, three 16 plant polycross populations were produced using each index. Seed from the polycross populations was used to establish a replicated space planted evaluation nursery near Clayton, NC. Cycle 0 or base population plants were included in the nursery to serve as a reference base. Index 1 resulted in increased yield, increased NDF and ADF but decreased IVDMD. Index 2 increased yield and resulted in nonsig- nificant changes in NDF, ADF, and IVDMD. Yield improvement was less than for Index 1. Index 3 resulted in a decrease in yield, decrease in NDF and ADF, and an increase in IVDMD. Gains in IVDMD were achieved but only with associated loses in yield. Economic weights were not used in developing the indexes. These results were predictive of selection for high IVDMD in the Agricultural Research Service, USDA and University of Nebraska (NE-USDA) EY x FF switchgrass population.

In the NE-USDA program, however, the selection for high yield and high IVDMD has been practiced using a selection index that weights both traits equally. This index was used to develop the cultivar Shawnee. Shawnee has biomass yields equivalent to the parent population, the cultivar Cave-in-Rock, but has higher IVDMD that results in higher digestible yield per acre (Table 4). These results and the results achieved by generations of breeding for high yield and high IVDMD in bermudagrass as summarized by Vogel and Sleper (1994) demonstrate that it should be feasible to improve both yield and quality traits in herbaceous plants. In the future, the most effective methods to improve both yield and quality traits using conventional breeding methods will involve the use of selection indexes in which molecular markers, conventional quantitative data, and economic weights are used. However, to be most effective in modifying herbaceous plants for conversion to liquid fuels, quality factors affecting conversion to liquid fuels need to be identified and economic weights assigned to them in relationship to biomass yield.

\section{Utilization of Genetic Markers to Enhance Plant Breeding Effectiveness}

Plant breeders using conventional plant breeding methods evaluate phenotypes. A phenotype is the product of the genotype of a plant as it is modified by the environment in which it is grown. Heritability estimates provide an indication of the magnitude of the environmental effect for a particular trait. For many important traits such as yield or IVDMD that are the result of the actions of many genes, heritabilities are usually 0.30 or 
lower, which indicates that only $30 \%$ of the total phenotypic variation that is measured is due to genetic differences among individuals. The efficiency of plant breeding could be greatly enhanced if breeders could directly measure or identify genotypes. Molecular markers can provide breeders with the ability to identify desired alleles or quantitative trait loci (Brummer, 1998). Molecular markers are currently being used or their use is being evaluated in most of the major grain crops and some initial work has been done in some forage crops such as alfalfa and tall fescue (Festuca arundinaceae Schreb.) (Brummer, 1998). The rapidly developing field of genomics includes the use of molecular markers and involves an array of sophisticated and expensive technologies (Liu, 1998). Knapp (1998) recently presented a theory for estimating the probability of selecting one or more superior genotypes by using markerassisted selection (MAS), and then used this information to estimate the cost efficiency of markerassisted selection relative to conventional phenotypic selection. His results indicate that MAS substantially decreases the resources needed to accomplish a selection goal for a low to moderately heritable trait when the selection goal and the selection intensity are high. Most of the MAS research to date is on diploid species or for polyploid species such as wheat for which considerable conventional marker data are available. Most forage or biomass species are cross-pollinated polyploids and limited conventional marker data are available, and the use of MAS for these genetically complex species will likely be more difficult than for grain and oilseed crops.

In a recent view, Sleper and Chen (1998) described the molecular marker tools that can be used in forage grasses, including RFLPs (Restriction Fragment Length Polymorphisms), RAPD (Random Amplified Polymorphic DNA), Variable Number Random Repeats (mini-satellites and micro-satellites), and AFLPs (Amplified Fragment Length Polymorphism). All methods have advantages and disadvantages. To date in switchgrass, a chloroplast RFLP marker has been identified that can be used to differentiate lowland and upland ecotypes (Hultquist et. al., 1996 ) and Gunter et al. (1996) used a set of RAPD markers to evaluate genetic relationships among released switchgrass cultivars and experimental stains. A molecular map for switchgrass has not been developed to date. The Herbaceous Energy Crops Program, Oak Ridge National Laboratory is funding research at the Oak Ridge National Laboratory and the University of Georgia to develop a molecular map for switchgrass based on simple sequence repeats (SSR) (personal communication, J. Bouton and L. Gunter with co- author, K. Vogel, 1999). Research would then have to be conducted to link molecular markers to genes controlling bioenergy traits in switchgrass.

Identification of quantitative trait loci (QTLs) for use in marker assisted selection has only just begun for cell wall traits. A series of QTLs were identified for ADF (presumed to consist of cellulose, lignin, cutin, and ash) in whole maize plants harvested at silage maturity (Lubberstedt et al., 1997). Unfortunately, the authors only reported QTL data for a calculated forage quality trait (metabolizable energy content, MEC) derived from ADF. These two traits were highly correlated $(r=$ -0.98) and, according to the authors, gave "almost identical results in QTL analyses" (Lubberstedt et al., 1997). Over two experiments, 15 QTLs for MEC were found spread over nine of the 10 corn chromosomes with very little overlap of QTLs between experiments. The individual QTLs accounted for 3 to $10 \%$ of the variation in MEC and in combination these QTLs accounted for 16 and $24 \%$ of the variation in MEC in the two experiments.

A second QTL study has been done in corn where the components of the cell wall (individual neutral sugars, uronic acids, lignin concentration and composition, and ester- and ether-linked hydroxycinnamic acids) were examined (Jung, $\mathrm{Ni}$, and Phillips, unpublished). In a preliminary report ( $\mathrm{Ni}$ et al., 1998), five to 15 QTLs were identified for each lignification trait (except lignin concentration for which no significant QTLs were found) and in combination these QTLs accounted for 52 to $96 \%$ of the phenotypic variation. For the polysaccharide components, 7 to 15 QTLs were found for each sugar residue and these accounted for 73 to $94 \%$ of the variation in combination. Twenty percent of the polysaccharide component QTLs were found on chromosome five and several QTLs were shared by both 
polysaccharide and lignification traits. These overlapping QTLs may be involved in coordinated deposition of the various polymers comprising the cell wall ( $\mathrm{Ni}$ et al., 1998).

The only other marker research concerning cell wall traits of which we are aware is an international project. Working with barley (Hordeum vulgare L, pearl millet (Pennisetum glacum (L.) R.Br), perennial ryegrass (Lolium perenne L.), and Brachiaria to improve their digestibility by livestock, several international centers in the CGIR network and the Australian Center for International Agricultural Research are searching for QTLs for a variety of cell wall traits. No results from this project have been published to date. Development of a molecular map for switchgrass and other potential herbaceous biomass species and associated markers is needed for use in markerassisted selection. Plants from the High IVDMD and low IVDMD switchgrass populations developed by the USDA-ARS breeding program at Lincoln, NE, could be used to identify QTLs that control this complex trait in switchgrass and also identify QTLs affecting winter survival. Research to date indicates that genes and their structural organization within genomes of Gramineae have a high degree of similarity (Stuber et al., 1999). Comparative maps and mapping information from other species should be very useful in developing markers for marker-assisted selection in switchgrass. In addition, significant advances are being made in understanding the genetic control of cell wall synthesis in model species such as Arabidopsis (Arabidopsis thaliana (L.) Heynh.), which should enable specific genes to be targeted in marker-assisted selection.

\section{E. Modifying Feed and Biomass Composition Using Plant Transformation Technologies}

Genes that are available for plant breeders to manipulate using conventional breeding methods are those that a species has accumulated during its evolutionary history. Until very recently, the only genes that were available to a breeder for improving a species in a conventional breeding program were the genes that were in the plants of the species or its close relatives. Genes can be moved between plants of closely related species with varying degrees of difficulty. Moving genes between unrelated species is not possible using conventional breeding methods. Molecular genetic approaches have and are making it possible to clone genes from virtually any living organism and insert the cloned gene into another organism, including forage plants. The transformed plants express the cloned genes and produce the gene products of the inserted gene. Molecular genetics and transformation procedures give plant breeders the potential to use genes from any organism to improve a plant species.

Conger (1998) recently reviewed transformation research on forages. Genetic transformation has been reported in several forage grasses, including orchardgrass, tall fescue, red fescue $(F$. rubra L.), meadow fescue ( $F$. pratensis Huds), perennial ryegrass, creeping bentgrass (Agrostis stolonifera L.), and redtop (Agrostis gigantea Roth). In forages grasses, transformation has been accomplished by direct uptake of DNA by protoplasts or by microprojectile bombardment. Proof of the transformation has been by PCR techniques, Northern hybridization analysis of transcribed DNA, Western blot analysis of soluble protein gene products, and Southern blot hybridization of total genomic DNA. Alfalfa and other legumes also have been transformed. The most effective transformation method for dicots has been via Agrobacterium tumefaciens transformation procedures. Until recently this procedure was not effective for Gramineae because of their resistance to Agrobacterium. There have been recent reports of Agrobacterium mediated transformation of rice and maize (Conger, 1998; Ye, 2000). The particle bombardment or gene gun technology was a major advance in the transformation of monocots. There are several different types, but all appear to be effective if good protocols are developed. An effective transformation system requires a gene deliver system (gene gun or Agrobacterium), appropriate tissue and regeneration systems (embryonic calls cells or suspension culture cells), desirable genes, promoter genes, and selectable marker genes. All components are now available for transformation of forage grasses. To date the genes of most interest have been for 
herbicide and insect resistance, but genes for modifying forage quality are also of interest.

Plant transformation technologies for switchgrass are being developed by Dr. Bob Conger and his associates at the University of Tennessee with the support of the Herbaceous Crops Program, Oak Ridge National Laboratory. This research effort was initiated in 1992 and since that time efficient and repeatable methods for regenerating switchgrass plants from in vitro cultured cells and tissues have been developed (Denchev and Conger, 1994; Alexandrova et al., 1996 a,b), including the recent development of a method for regenerating switchgrass plants from cells in suspension culture (Dutta and Conger, 1999). A nursery with 1000 regenerated plants has been established at the University of Tennessee (Conger et al., 1999). Recently, Conger has transformed switchgrass by bombarding switchgrass cells with tungsten particles coated with the plasmids psGFP-Bar and pAHC25 and has achieved the expression of both green fluorescent protein (gfp) and uidA, which codes for the GUS (beta-glucuronidase) (Personal communication with B. Conger, Oct. 15, 1999; Conger et al., 1999). Punitively transformed switchgrass plants $\left(\mathrm{T}_{0}\right.$ generation) are currently growing in a University of Tennessee greenhouse. Some plants are resistant to Basta, indicating the presence of the bar gene. The transformed plants will need to be advanced several generations to ensure that the transformations are stable. Although improvements in the technology will undoubtably be made, Conger and his associates have developed the basic technology to employ transformation as a breeding procedure in switchgrass.

Conger (1998) and others have pointed out that the release of transgenic forage plants could have environmental effects because many forage plants have wild relatives. Traditionally, most of the traits in plants modified by plant breeders, including dwarfing, absence of dormancy, nonshattering seed, and uniform maturity, have an adaptive disadvantage in the wild. Some traits for which plants could be transformed could have an adaptive advantage in the wild including resistance to biotic and abiotic stresses. It is possible that these genes could be transferred to wild, relatives via sexual hybridization. The presence of such genes in wild relatives could have undesirable economic and environmental consequences.

\section{Potential Targets for Molecular Manipulation}

In a 1994 review on plant cell walls, it was concluded that for cell wall polysaccharides "not a single biosynthetic enzyme has been purified to homogenity and not a single gene for any such enzyme has been cloned" (Reiter, 1994). In the ensuing 5 years this situation has changed dramatically for cellulose biosynthesis (Delmer, 1999), but only minimal progress has been achieved for hemicellulose or pectin synthesis. In contrast, the molecular biology of lignification has progressed to the point where virtually every enzyme for monolignol synthesis has been cloned, and many research groups are actively producing and evaluating transgenic plants (Baucher et al., 1998). The following discussion covers the current knowledge of the biosynthetic pathways, genes isolated to date, and reported results with transgenic plants for the cell wall polymers.

\section{Lignin}

Lignin is synthesized from monolignols produced in the shikimic acid pathway (Figure 5). Baucher et al. (1998) provide an excellent current review of the biochemistry and molecular biology of lignification. The monolignol biosynthesis pathway has been described as a web because of the many possible routes of synthesis (Sewalt et al., 1997). More recently, Chiang and co-workers (Osakabe et al., 1999; Li et al., 1999; Li et al., 2000) have proposed that the major flux of lignin biosynthesis passes through caffeic acid to caffeoyl-CoA to feruloyl-CoA, and then to coniferyaldehyde. This route bypasses ferulic and sinapic acids as lignin precursors. The conversion to sinapyaldehyde occurs at the aldehyde level in this modified biosynthetic pathway (Osakabe et al., 1999; Li et al., 1999; Li et al., 2000). A unique aspect of lignin biosynthesis is that the polymerization reaction occurs as a free-radical reaction of monolignols outside the cell's cytoplasm in the 


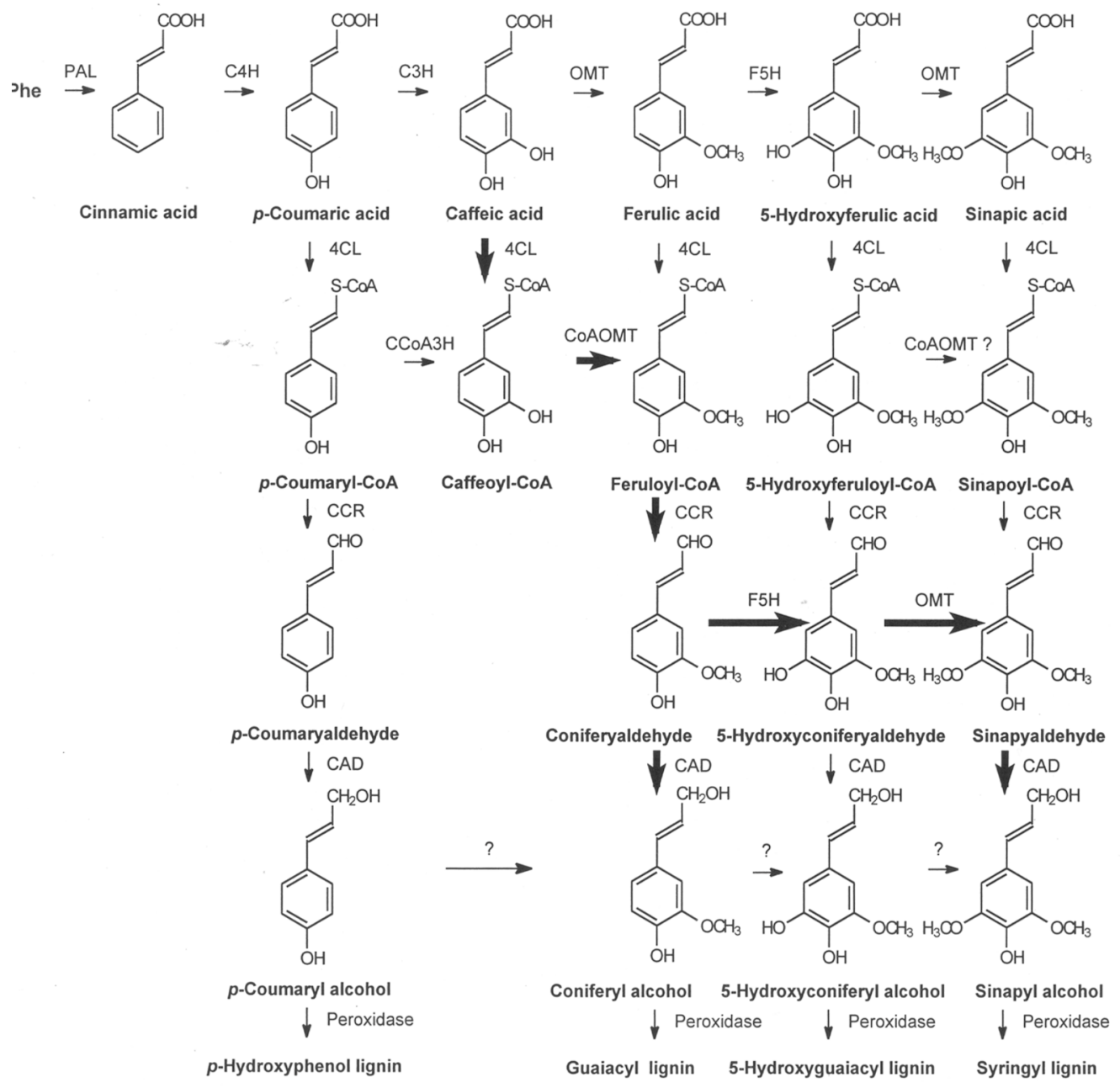

FIGURE 5. A schematic representation of the lignin biosynthetic pathway starting from phenylalanine (Phe). Tyrosine is the second precursor to this pathway via tyrosine ammonia lyase to form $p$-coumaric acid. The enzymes involved in lignin synthesis include: $\mathrm{PAL}$, phenylalanine ammonia lyase; $\mathrm{C} 4 \mathrm{H}$, cinnamate 4-hydroxylase; $\mathrm{C} 3 \mathrm{H}$, 4coumaroyl hydroxylase; OMT, O-methyltransferase; $\mathrm{F} 5 \mathrm{H}$, ferulate 5-hydroxylase; 4CL, 4-coumarate-CoA ligase; $\mathrm{CCoA3H}$, 4-coumaroyl-CoA hydroxylase; CoAOMT, caffeoyl-CoA O-methyltransferase; CCR, cinnamoyl-CoA reductase; $C A D$, cinnamyl alcohol dehydrogenase, and peroxidase. The bold arrows indicate the major route of lignin synthesis as proposed by Chiang and co-workers (Osakabe et al., 1999; Li et al., 1999; Li et al. 2000). All genes in the lignin biosynthesis pathway have been cloned except for 4-coumarate 3-hydroxylase.

cell wall. Only a single gene for an enzyme in the monolignol pathway ( $p$-coumaric acid 3-hydroxylase) has not been cloned. All the other genes have been cloned, usually from numerous plant species, and generally multiple copies of each gene have been cloned from individual species. While monolignol synthesis has been well characterized, how the monolignols are transported to the cell wall for polymerization is still unclear (Reiter, 1994). The enzyme (peroxidase and/or laccase) responsible for monolignol polymerization has yet to be determined. In grasses, ferulate esters of arabinoxylans appear to serve as nucleation sites for lignin polymerization (Ralph et al., 1995), although mutant corn plants selected for reduced concentrations of ferulate esters in seedling leaves were shown to deposit normal amounts of lignin in the wall (Jung et al., 1999a). While ferulates act as lignin/polysaccharide cross-linking agents in the Gramineae, similar cross-linking structures have not been identified in other plant groups.

The brown midrib (bmr) mutants of annual $\mathrm{C} 4$ grasses (maize, sorghum, and pearl millet 
(Pennisetum glacum (L.) R.Br.) have served as models for scientists interested in modifying lignification through biotechnology. Four spontaneous $b m r$ mutants have been identified in corn, and the mutated genes are on different chromosomes (Neuffer et al., 1968). The specific genes affected in these $b m r$ mutants have been determined for two of the mutants (bmr3 and $b m r l$ ). Two independent mutations have been identified in the $O$ methyltransferase (OMT) gene of bmr3 maize (Vignols et al., 1995). This enzyme catalyzes the methylation of the 3- and 5-position hydroxyl groups on the aromatic ring structures of caffeic and 5-hydroxyferulic acids, respectively, in monolignol synthesis. The net result of the $b m r 3$ mutation is a reduction in both the total amount of lignin deposited in the cell wall and a shift in lignin composition away from syringyl-type lignin because conversion of 5-hydroxylferulate to sinapate is required for syringyl lignin synthesis. Recently, bmrl corn was shown to be caused by a mutation in the cinnamyl alcohol dehydrogenase gene (CAD, Halpin et al., 1998). The CAD enzyme converts cinnamyl aldehydes to their alcohol derivatives in the last step of monolignol synthesis. The bmrl mutation also reduces lignin concentration, but not as severely as bmr3. A spontaneous $C A D$ mutant in loblolly pine (Pinus tneda L.) has been described in which CAD enzyme activity is almost completely absent, but lignin concentration is only nominally affected (MacKay et al., 1997). This pine mutant incorporated cinnamyl aldehyde units, as would be predicted from reduced CAD activity, in addition to the normal alcohol monolignols (Ralph et al., 1997). The genes affected in the bmr2 and bmr4 maize mutants have not yet been identified.

Biotechnologists have created antisense and sense-suppressed transgenic tobacco (Nicotiana tabacum L.) for both the $O M T$ and $C A D$ genes (Baucher et al., 1998). Ni et al. (1994) found 15 to $57 \%$ reductions in lignin concentration due to an antisense alfalfa $O M T$ transgene, but surprisingly lignin composition (syringyl-to-guaiacyl ratio) was not altered. Because the OMT enzyme is involved in syringyl lignin precursor synthesis, a change in lignin composition would be expected. In contrast, when an aspen (Populus tremuloides Michx.) antisense $O M T$ transgene was inserted into tobacco, lignin concentration was not affected, while lignin composition did shift to a reduced syringyl lignin content (Dwivedi et al., 1994). The use of the tobacco antisense OMT cDNA in tobacco resulted in a drastic reduction in syringyl lignin content with no change in lignin concentration (Atanassova et al., 1995). The causes for these inconsistent results are not known. Results for $C A D$ transgenic plants with reduced enzyme activity have been more consistent with all reports to date indicating no change in lignin concentration compared with normal tobacco plants, but alterations have always been observed in lignin composition (Hibino et al., 1995; Stewart et al., 1997; Yahiaoui et al., 1998).

In addition to $O M T$ and $C A D$ transgenics, the genes for phenylalanine ammonia-lyase, cinnamic acid 4-hydroxylase, caffeoyl-CoA $O$ methyltransferase, cinnamoyl-CoA reductase, and peroxidase have all been used to transform tobacco (Baucher et al., 1998). As with the OMT and $C A D$ genes, in some cases lignin concentration and/or composition were altered by these other transgenes, whereas in other cases little response was noted. Because of the complexity of the monolignol biosynthetic pathway, the prediction of plant phenotype of transgenic plants has been difficult. As Ralph et al. (1998b) showed, transgenic plants can make lignin from a variety of monolignol precursor molecules that result in nontypical but apparently functional lignin polymers.

The impact of biotechnology on cell wall digestibility has only been assessed in a few studies dealing with manipulation of lignification genes. When OMT and CAD activities were downregulated in tobacco, lignin concentration was not altered, but composition of the lignin shifted toward a reduced syringyl lignin content (Bernard Vailhe et al., 1996; 1998). This reduction in syringyl lignin was associated with increased in vitro cell wall digestibility. Similar correlations of improved digestibility with reduced syringyl content of lignin have been observed in the bmr mutants (Cherney, 1990) and led Jung and Deetz (1993) to hypothesize that lignin composition as measured by the syringyl-to-guaiacyl ratio influenced the digestibility of forage cell walls. However, results with induced lignification in a corn 
cell culture system have indicated that monolignol composition does not impact cell wall digestibility (Grabber et al., 1997), and cell wall digestibility was also not impacted by the fahl mutant in Arabidopsis that produces no syringyl lignin whatsoever (Jung et al., 1999b). When Sewalt et al. (1997) evaluated down-regulation of phenylalanine ammonia lyase and OMT activities in transgenic tobacco they observed improved cell wall digestibility associated with both reduced lignin concentration and decreased syringyl lignin content. These authors attributed the improved digestibility to the reduction in lignin concentration rather than altered lignin composition.

In the first published report concerning the impact on digestibility from manipulating lignification in a forage species, Sewalt et al. (1996) observed that down-regulation of OMT and the caffeoyl-CoA form of OMT resulted in modest reductions in lignin concentration and/or syringyl lignin content in alfalfa, plus reduced NDF concentration. Enzymatic digestion of NDF was only slightly improved in some transgenic lines, but when coupled with the reduced NDF concentration dry matter digestibility was positively correlated with lignin concentration. More recently, Baucher et al. (1999) reported that reduced CAD activity decreased syringyl lignin content but not lignin concentration in alfalfa. Cell wall digestibility measured in situ was increased for a few transgenic lines with reduced CAD activity when grown in the greenhouse; however, none of the $C A D$ transgenic lines exhibited significant increases in cell wall digestibility when grown under field conditions (Baucher et al., 1999). While improvements in forage digestibility are expected from manipulation of the lignification pathway, these benefits must await more consistent success in reducing lignin concentration as altering lignin composition does not appear to be a reliable method to increase cell wall digestibility.

Surprisingly, there have been no reports for transgenic maize, or other grasses, with respect to the lignification genes. Given the availability of DNA sequences for these genes, it must be assumed that plant biotechnology companies are creating and evaluating such transgenics. Data have been reported for transgenic hybrid poplar trees (Baucher et al., 1998) and alfalfa (Sewalt et al., 1996; Baucher et al., 1999). The primary practical goals of these research efforts are to develop forage crops that have more digestible cell walls for animal feeding and trees that have improved pulping characteristics for paper production. Several reports on lignin transgenic plants have noted abnormal growth and developmental characteristics (Lee et al., 1997; Piquemal et al., 1998; Ralph et al., 1998b; Tamagnone et al., 1998). In a recent commentary on genetic modification of lignification, Jung and Ni (1998) concluded that when transgenic plants exhibited significant reductions in lignin content some abnormal growth and development were observed. These results are consistent with the reduced winter survival of the High IVDMD C3 switchgrass progeny discussed previously. The abnormal growth has generally been associated with a weakened vascular system caused by collapsed vessels (Lee et al., 1997). However, Hu et al. (1999) have now reported that antisense down regulation of the 4-coumarateCoA ligase gene in aspen reduced lignin deposition by $45 \%$ without any detrimental impact on growth. This positive result for reduced lignin concentration in aspen is in contrast to previous reports for other lignification genes in herbaceous plants. Perhaps the very high cell wall and lignin concentrations in trees allow greater tolerance of lignin reductions. The requirement for lignin in vessel development is logical given that the first water transport tissue (protoxylem) lignifies long before adjacent tissues complete their elongation or begin to lignify (Engels and Jung, 1998). In contrast, even extreme alterations in lignin composition, such as the fahl mutant of Arabidopsis, which produces no syringyl lignin whatsoever (Chapple et al., 1992), do not affect plant growth. Jung and $\mathrm{Ni}$ (1998) hypothesized that lignin quantity may play a more important role in plant growth than lignin composition and structure. Because of the importance of lignin to plant development, one of the authors of this review (HGJ) is engaged in a project to clone the gene for synthesis of the feruloylarabinoxylan ester in corn as a way to reduce cross-linking of lignin to cell wall polysaccharides, and thereby increase cell wall digestibility, without reducing lignin concentration (Ni et al., 1997; Jung et al., 1999a). 


\section{Cellulose}

Unlike lignin polymerization, which occurs in the cell wall, cellulose is synthesized at the plasma membrane by rosette-shaped complexes (Reiter, 1994). Each plant cellulose microfibril contains $36 \beta-1,4$ glucan chains, requiring that synthesis of glucan chains by the multiple units comprising each rosette complex be highly synchronized (Delmer, 1999). UDP-glucose is the substrate for cellulose synthesis, but the basic repeating unit of cellulose is the dimer cellobiose, and confusion remains as to how the $180^{\circ}$ shift in orientation of adjacent glucose residues in cellulose is achieved. The cellulose of higher plants is predominately in the $\mathrm{I} \beta$ allomorph form. Crystallization of cellulose occurs through $\mathrm{H}$-bonding of glucose residues and van der Walls forces between adjacent glucan chains.

Several mutations in cellulose deposition have been identified. "Brittle" mutants exhibiting reduced mechanical strength of culms have been described in barley (Hordeum vulgare L.), maize, and rice (Oryza sativa L.) (Reiter, 1994). The barley "brittle" mutant was shown to have reduced cellulose concentration, and this decrease in cellulose was due to a reduction in the number of cellulose molecules rather than a decreased degree of cellulose polymerization (Kokubo et al., 1989; 1991). An Arabidopsis mutant (tbr) has been identified that exhibits reduced deposition of highly ordered cellulose in secondary walls of specific tissues (Potikha and Delmer, 1995). Three mutants (irxl-3) that cause collapse of xylem cells in Arabidopsis stems were found in a mutagenized population (Turner and Somerville, 1997). The irx3 mutant has been shown to contain reduced cellulose content (Taylor et al., 1998). The $r s w-1$ Arabidopsis mutant produces a less crystalline cellulose at the same time total cellulose deposition is reduced (Arioli et al., 1998). This particular mutation is expressed during primary cell wall development under high growth temperatures and causes the rosette structures associated with cellulose synthesis to disintegrate. It appears that the irx3 mutant is specific for secondary wall cellulose synthesis, whereas the $r s w$ - 1 mutant is localized to the primary wall (Taylor et al., 1999).
In contrast to the extensive work on molecular manipulation of lignification, similar research with respect to cellulose synthesis is just beginning. Recently, Delmer (1999) has reviewed both the history and current status of research on cellulose synthesis. Acetobacter xylinium has long served as the model organism for research on cellulose synthesis because researchers have failed in their attempts to induce plant tissues cultures to produce cellulose. In 1990, a cellulose synthase gene was cloned from this bacterium (Saxena et al., 1990). In 1996, Delmer's group finally cloned two cDNAs for cellulose synthase from a cotton fiber library that showed only limited homology to the bacterial cellulose synthase gene (Pear et al., 1996). The identification of the four domains required for UDP-glucose binding allowed the identification of the plant homologs to the bacterial gene. A recent search of GenBank indicated that additional cellulase synthase genes have been isolated from Arabidopsis, rice, and poplar. Unpublished work, cited by Delmer (1999), indicated that ESTs for cellulase synthase have been identified in maize. As observed for most genes in the lignin pathway, numerous copies of cellulase synthase have been found in individual plant species (Delmer, 1999).

Many transgenic plants have been created with several different lignin genes, but there have been few reports of similar transgenic experiments with respect to cellulose synthesis. Arioli et al. (1998) showed that the rsw-1 Arabidopsis mutant was due to a defect in a cellulose synthase gene and complementation with the normal gene restored the wild-type phenotype to transgenics created from the $r s w-1$ mutant. Insertion of an antisense wild-type $R S W-1$ cellulose synthase gene construct into Arabidopsis resulted in most of the same growth abnormalities as observed in the original mutant, although the phenotypes were unstable and tended to revert to wild type (Burn et al., 1998). The only other reported transgenic experiment dealing with cellulose synthesis examined the addition of the cellulose binding domain gene from the endo-1,4- $\beta$-glucanase of Clostridium cellulovorans on plant growth (Shani and Shoseyov, 1999). Young transgenic poplar trees grew more rapidly with insertion of the cellulose binding domain transgene. When the cellu- 
lose binding domain protein was added to cultures of Acetobacter xylinum, cellulose synthesis increased in a dose-responsive manner (Shpigel et al., 1998). The addition of the cellulose binding domain protein to culture media also enhanced peach (Prunus persica Batsch.) pollen tube elongation and Arabidopsis root elongation. The mode of action hypothesized for this increased plant elongation is that the cellulose binding domain protein competes with xyloglucans for binding to individual $\beta-1,4$ glucan chains, thereby temporarily preventing hydrogen bonding in cellulose microfibrils (Shani and Shoseyov, 1999; Shpigel et al., 1998).

\section{Other Cell Wall Polysaccharides}

The synthesis of hemicelluloses and pectins requires the transformation of UDP-glucose to other sugar residues (xylose, arabinose, galactose, rhamnose, mannose, galacturonic acid, and glucuronic acid) (Reiter, 1994). GDP-mannose is converted to GDP-fucose by a separate pathway (Figure 6). These sugars are then assembled into complex, branched polysaccharides by as yet unidentified enzymes. Unlike lignin synthesis, occurs in the cell wall itself, and cellulose, which is synthesized at the plasma membrane, hemicelluloses and pectins are assembled intracellularly in the Golgi (Delmer and Stone, 1988). Feruloylation of arabinoxylans in grasses also occurs during this intracellular assembly process (Myton and Fry, 1994). While extensive literature exists on hemicellulose and pectin structures, the lack of knowledge concerning the synthesis of polysaccharides has severely limited progress toward the manipulation of the pathways.

The only characterized mutations for hemicellulose and/or pectin deposition in the cell walls of plants were derived from a screening project involving 5000 chemically mutagenized Arabidopsis plants (Reiter et al., 1993). Leaf cell walls were analyzed for major shifts in sugar composition in this study. Mutants were categorized into those lines that (1) had complex changes in relative amounts of several sugars, (2) a substantial reduction in a single sugar constituent of the cell wall, or (3) lines that were completely deficient in a specific cell wall sugar (Reiter, 1994). Category 1 mutants had altered growth characteristics and category 2 lines had substantial reductions in arabinose or fucose without any change in growth habit from the wild-type plants. The murl mutant of Arabidopsis was severely deficient in fucose content ( $<2 \%$ of normal) and the only line falling in category 3 (Reiter et al., 1993). This mutation caused a slight dwarfing and decreased apical dominance. Cell wall fucose in the roots was only reduced by $40 \%$ in the murl plants compared with the almost complete absence of fucose in leaf cell walls. Recently, the murl mutation was shown to be due to a defect in the GDP- mannose-4,6-dehydratase gene that catalyzes the first step in the conversion of GDPmannose to GDP-fucose (Bonin et al., 1997).

Only five other genes for cell wall sugar synthesis have been cloned to date. The UDP-glucose pyrophosphorylase gene has been cloned from potato and barley (Katsube et al., 1990; Eimert et al., 1996). This gene encodes the enzyme for conversion of glucose 1-phosphate to UDP-glucose. The gene for UDP-glucose epimerase has been isolated from Arabidopsis (Dormann and Benning, 1996), and the UDP-glucose dehydrogenase gene has been isolated from soybean (Glycine $\max$ (L.) Merr.) (Tenhaken and Thulke, 1996). These enzymes convert UDP-glucose to UDP-galactose and UDP-glucuronic acid, respectively. These reactions are involved in synthesis of the precursors to both hemicellulose and pectin. The UDP-glucose dehydrogenase enzyme has been hypothesized to be a key regulatory step for hemicellulose synthesis because it transfers carbon from glucose to the pentose sugars (xylose and arabinose) (Amino et al., 1985). The GDPmannose pyrophosphorylase gene, which converts mannose to fucose, has been cloned from potato (Solanum tuberosum L.) (Keller and Kossmann, 1998). Most recently, Perrin et al. (1999) reported the isolation of a xyloglucan fucosyltransferase from Arabidopsis. This is the first gene that has been cloned for a step in hemicellulose assembly.

There has been only one published report with transgenic plants concerning the synthesis of hemicellulose or pectin. The reduction of GDPmannose pyrophosphorylase activity by a transgene from potato resulted in reduced man- 


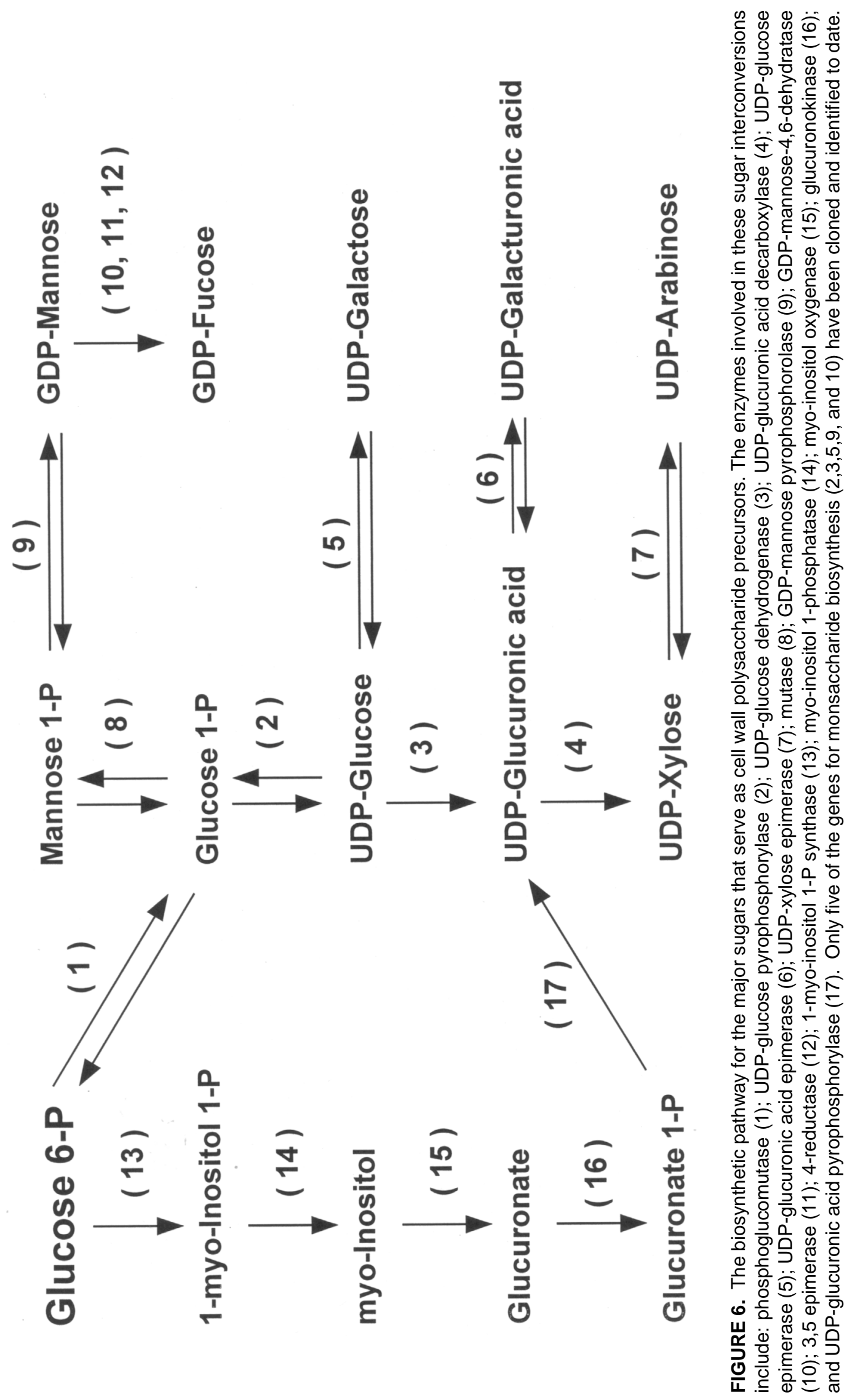


nose concentration in the leaves, but did not reduce fucose content as expected, and resulted in premature senescence as the plants matured (Keller and Kossmann, 1998). One of the authors of this review (HGJ) is involved in an attempt to increase pectin deposition in alfalfa by addition of a sense construct of the soybean UDP-glucose dehydrogenase gene because of this enzyme's presumed regulatory role in sugar interconversions for cell-wall polysaccharide synthesis (Amino et al., 1985). While the presence of the transgene has increased UDP-glucose dehydrogenase activity in transgenic alfalfa plants, its impact on pectin concentration in the cell wall has not yet been determined (Jung, Samac, and Somers, unpublished). The extreme paucity of information on polymer synthesis of the noncellulosic polysaccharides and very limited number of genes cloned for sugar precursor synthesis undoubtedly accounts for the lack of transgenic attempts to manipulate hemicellulose and pectin synthesis.

As indicated above, there are an array of synthesis pathways in herbaceous plants such as switchgrass that could be genetically manipulated via plant transformation. The creation and characterization of an expanded array of cell wall mutants in grasses would tremendously aid our study of polysaccharide biosynthesis and subsequent cloning of the genes involved in cell wall composition and assembly. However, until the conversion technology is known and desirable feedstock parameters are delineated, it will be difficult for geneticists to know what genes to use in plant transformation research to improve the feedstock qualities of herbaceous species such as switchgrass. The affect of single gene transformation on whole plant phenotypes needs to be monitored, including the stability of trait expression over environments.

\section{F. Environment and Ecosystem Constraints on the Use of Genetically Modified Organisms}

There is currently considerable debate over the desirability and safety of transgenic plants, and the issue is complicated because the arguments against the use of genetically modified or- ganisms are based on scientific, economic, political, and religious grounds (Duvick, 1999). As pointed out by Duvick (1999), the primary scientific issue is safety. Transformed feed and biomass plants must be safe for use by animals (domestic or wild) and also be ecologically safe to be utilized in production systems. They must not have the capacity to develop into super weeds. Their potential for affecting germplasm resources also needs to be considered, and this is the main issue that could limit the use of transformed plants in biomass production systems.

Switchgrass was one of the dominant grasses of the North American Tallgrass Prairie and it is generally associated with the natural vegetation of the Great Plains and the western Corn Belt (Moser and Vogel, 1995). It was also found in grasslands and nonforested areas throughout North America east of the Rocky Mountains and south of $55^{\circ} \mathrm{N}$ latitude. Tallgrass prairie is a recently derived vegetation type (Steinauer and Collins, 1996). There was probably a woodland-grassland mosaic on the plains and prairies of North America before the Pleistocene. During the Pleistocene, the eastern Great Plains was covered by ice in the north and forest in the south. It was not until the Holocene that conditions conductive to continuous grasslands existed on the plains and prairies (Steinaurer and Collins, 1996). The tallgrass prairie existed as an ecosystem for over 12,000 years. In less than a 100 years, it has been largely converted to cultivated cropland. Except in the Great Plains states where extensive natural grasslands still exist in some regions, the native prairie and grassland sites where switchgrass occurs are scattered remnants. Since 1930, the decline (estimated to be 82 to $99 \%$ ) in area of the tallgrass prairie exceed those reported for any other major ecosystem (Sampson and Knopf, 1994). Only about 4\% of the presettlement Tallgrass Prairie remains. Throughout its former range, only small scattered fragments remain embedded in the nongrassland landscape (Steinaurer and Collins, 1996, Risser, 1996). Of The Nature Conservancy's 101 tall grass prairie preserves, 71 are less than $100 \mathrm{ha}$, and only 4 are greater than 1000 ha (Steinaurer and Collins, 1996). These small remnant prairies and grasslands constitute the in situ germplasm preservation reserve of switchgrass. The situation is 
similar in the eastern regions of the range of switchgrass in the North America.

Since the germplasm base for switchgrass consists of scattered small remnant populations there is concern among conservation biologists, including Nature Conservancy staff that species in these remnant populations could be genetically contaminated by native grass, legume, and forb cultivars developed using conventional breeding methods. Recently, Frye (1999) discussed the potential problems that could occur due to gene transfer via seed or pollen and they include loss of genetic diversity by swamping of native genotypes or by the introduction of aggressive strains; loss of populations sizes and structure through the introduction of deleterious or lethal alleles; loss of evolutionary potential through genetic homogenization; unforeseen changes in plant-animal interactions; and loss of research potential utilizing native populations. Frye (1999) concluded that outbreeding contamination may not be a problem with long-lived perennials (such as switchgrass) but could likely be a problem with outcrossing annual species. This is an area of concern with the Nature Conservancy, which is one of the largest holders of remnant prairie and other grassland sites (Grove, 1988).

The deployment of transgenic switchgrass plants, particularly if they were altered with genes that could potentially affect fitness, would most likely be of major concern to many environmental groups in North America. Many of the groups that would likely be strongly politically opposed to the deployment of transgenic switchgrass plants are also those who currently are some of most the significant supporters of renewable biomass energy programs.

Transgenic switchgrass plants will be able to be released for use in biomass production systems only if their potential for genetic contamination of remnant switchgrass populations is virtually zero. Because genetic contamination can occur via seed or pollen, transgenic switchgrass plants must not be capable of producing either viable seed or pollen when grown in biomass production fields.

Technology has been developed recently that could be used in switchgrass to eliminate the feasibility of viable seeds being produced. This is the Technology Protection System or 'Terminator' technology that was jointly developed by the Agricultural Research Service, U.S. Department of Agriculture and the Delta and Pine Land Co.which is a major breeder of cotton (Gossypium hirsutum L.) and soybeans, and they have received U.S. Patent 5,723,765 on the technology (Service, 1998; United States Patent Office, 1999; USDA-ARS, 1999). The patent is jointly owned by USDA-ARS and Delta and Pine Land Co. and under the terms of the development agreement, Delta and Pine Land Co. have licensing rights. In a recent USDA-ARS Fact Sheet (USDA-ARS, 1999), ARS indicated that the technology would be made widely available for research in the public and private sectors and that Delta and Pine Land Co. has agreed to make the technology widely available for sublicensing to other seed companies.

Similar technology to produce plants that do not produce viable pollen has not been developed to date. Male sterile genes exist in most plants species, and it is likely that some mechanism involving the manipulation of male sterility could be developed. In contrast to crops in which seed is the primary product and for which viable pollen is needed to produce a crop, a biomass crop does not have to produce seed. Seed is needed only to establish production fields. Technology to eliminate the production of viable pollen in switchgrass or other herbaceous biomass crops but still enable seed to be produced in seed production fields will probably be needed before genetically transformed switchgrass plants will be able to be released for use in agricultural production. Methods to limit the flow of genes from other transformed herbaceous species to their wild relatives will likely be needed.

\section{G. Feed and Feedstock Quality Assessment in Genetic and Breeding Research}

Information in the previous sections have clearly demonstrated that switchgrass and other herbaceous biomass feedstocks can vary in desirable quality traits due to differences in date of harvest, environment during the growing season, 
harvesting and storage practices, and because of inherent genetic differences among the strains. Variation in biomass quality due to a combination of all the nongenetic factors can likely exceed any genetic differences among cultivars, including potential genetic differences achieved by transformation. Breeders will have to be able to measure feed and feedstock quality on a large array of plant materials grown in different environments and harvested at different states of physiological maturity to determine the magnitude of genetic changes and their stability over environments. Rapid, reliable, and repeatible analytical technologies are needed that have a low per sample cost. Near infrared reflectance spectroscopy or NIRS (Shenk and Westerhouse, 1994, 1995; Marten et al., 1989) meets these criteria. This technology was developed to determine quality of agricultural products, including protein and oil content of grains and oilseeds, and was adapted to measure forage quality parameters. With this technology, ground samples are scanned with near-infrared radiation in monochromatic 2 to $10 \mathrm{~nm}$ increments in the 700 to $2500 \mathrm{~nm}$ near-infrared region and the reflected radiation is measured. The spectrum of the sample can then be statistically compared with the spectra from a set of calibration samples and its chemical composition can be determined. The calibration samples must be representative of the range of plant materials expected to be analyzed and the composition of the calibration samples must be determined using standard procedures. NIRS has been demonstrated to be an effective technology that can be used to determine IVDMD, NDF, ADF, cell wall total monosaccharides, arabinose, xyulose, galactose, glucose, and hexose and pentose sugars of switchgrass and other grasses (de Ruiter and Burns, 1987; de Ruiter et al., 1988; and Godshalk et al.,1988b). NIRS has been used by the NEUSDA switchgrass breeding program for over 10 years to analyze switchgrass forage for IVDMD, $\mathrm{NDF}, \mathrm{ADF}$, and ADL in both breeding and genetics studies. As biomass quality parameters are delineated by conversion research, breeders and chemists working on biomass conversion will need to coordinate efforts to develop NIRS calibrations sets for these parameters so that breeders can use them in their feed and feedstock improvement programs.

\section{SUMMARY AND RESEARCH RECOMMENDATIONS}

It should be highly feasible to genetically modify the feed and feedstock quality of switchgrass and other herbaceous plants using both conventional and molecular breeding techniques. The effectiveness of breeding to modify herbages of switchgrass and other perennial and annual herbaceous species has been demonstrated already. The use of molecular markers and transformation technology may greatly enhance the capability of breeders to modify the plant structure and cell walls of herbaceous plants. It will be necessary to monitor gene flow to remnant wild populations of plants and have strategies available to curtail gene flow if it becomes a problem. It also will be necessary to monitor plant survival and long-term productivity as affected by genetic changes that improve forage quality. Specific recommendations to facilitate this process include:

1. The relative economic value of herbaceous feed and feedstock quality characteristics that affect livestock performance or bioenergy conversion efficiency needs to determined particularly in relationship to biomass yield. It is unrealistic to expect breeders and geneticists to breed for specific traits without knowing their relative importance. Breeders will have to cooperate with animal scientists and biomass conversion scientists in this research.

2. Biomass samples for use in conversion research need to represent a wide range in quality parameters. This range in quality can be obtained by having samples collected at various stages of development from an array of characterized environments and storage conditions for target herbaceous species such as switchgrass and from genotypes within species known to differ genetically for biomass quality characteristics.

3. Conversion laboratories should characterize samples by NIRS analysis and other emerging rapid, automated analytical technologies and develop calibrations and procedures that can be used to analyse the biomass from the thousands of plants that are routinely exam- 
ined in genetic improvement and evaluation programs. The same procedures and calibration will be needed for buying feed and feedstocks on a quality basis.

4. Conventional breeding and genetic studies to date on forage or biomass quality have used the detergent system of analysis to determine lignin, cellulose, and hemicellulose concentrations. Recent research has clearly shown that acid detergent lignin underestimates lignin concentration that results in an overestimation of cellulose and hemicellulose concentrations. Genetic studies using both divergent selection and parentprogeny analysis need to be conducted on target species to determine the genetic variation for Klason lignin and other biomass energy specific traits.

5 .Molecular genetics technology should be used in several thrust areas. Molecular marker maps of switchgrass and other principal herbaceous species need to be developed to enable genetic differences identified via Recommendation 4 to be linked to specific genetic markers and utilized in marker assisted selection. The genetic markers will be needed to monitor potential gene flow from biomass crops with modified cell-wall traits to wild populations. Research on developing robust genetic maps and associated sets of markers are being initiated and should continue to receive support.

6 Lignin and cellulose synthase genes are being mapped and cloned by various research groups in an array of species. The impact of the use of these genes in candidate perennial biomass crops such as switchgrass and alfalfa need to be tested and evaluated. The research to date with herbaceous transgenic plants has been primarily on annuals. It should be feasible to determine the effect of the genes on feedstock quality, plant yield, and other traits of transformed plants by using vegetative ramets or clonal propagules of the transformed plants. Genes with desirable characteristics could then be evaluated for any potential deleterious environmental effects and if none, then used directly in genetic improvement programs.
7. To date, only seven genes (five for monomer synthesis, two for polymer assembly) have been cloned for cell wall polysaccharide synthesis. Only one screen in a mutagenized Arabidopsis population has been done for cell wall monosaccharide composition. Systematic screening for cell wall mutants has not been done in grasses other than for brown mid-rib genes. Additional genes, including genes that control cell wall composition as well as timing, and the site and extent of deposition of polysaccharides and lignin in cell walls very likely exist. Screening research for cell wall mutants in $\mathrm{C}_{3}$ and $\mathrm{C}_{4}$ grasses and legumes should be initiated. Emphasis should be on diploid, perennial species because any genes identified would already be capable of being used in a perennial such as switchgrass and because finding mutants in plants with high ploidy levels is extremely difficult. As an example, Medicago truncatula, a close diploid relative of alfalfa, could be used to identify cell wall mutants because mutagenized populations are already available and large-scale gene sequencing is underway.

8. Herbaceous plants are likely going to be modified to produce bio-products such as biodegradable plastics and vaccines. These products will likely have higher market value than liquid fuels from biomass. It would be extremely difficult to genetically modify plants for two or more different end uses. Rather that attempt to develop biomass plants with specific co-products, the biofuels program should instead concentrate on determining the bioenergy value of the residues derived from processing plants developed for other bioproducts. A notable exception is that attention could be focused on developing transgenic plants to produce the enzymes (cellulases and xylanases) needed to produce liquid fuels from biomass. These enzyme producing biomass plants must be capable of high levels of protein production, such as alfalfa, and could be directly combined with specialized biofuels species, such as switchgrass, during conversion or used as a source for enzyme extraction. 


\section{REFERENCES}

Alexandrova, K. S., P. D. Denchev, and B. V. Conger. 1996a. In vitro development of inflorescences from switchgrass nodal segments. Crop Sci. 36:175-178.

Alexandrova, K. S., P. D. Denchev and B. V. Conger. 1996b. Micropropagation of switchgrass by node culture. Crop Sci. 36:1709-1711.

Allard, R. W. 1964. Principles of Plant Breeding. John Wiley \& Sons, New York.

Amino, S., Y. Takeuchi, and A. Komamine. 1985. Changes in enzyme activities involved in formation and interconversion of UDP-sugars during the cell cycle in a synchronous culture of Catharanthus roseus. Physiol. Plant. 60:111-117.

Anderson, Bruce, J. K. Ward, K. P. Vogel, M. G. Ward, H. J.Gorz, and F. A. Haskins. 1988. Forage quality and performance of yearlings grazing switchgrass strains selected for differing digestibility. J. Anim. Sci. 66:2239-2244.

Arioli, T., L. Peng, A. S. Betzner, J. Burn, W. Wittke, W. Herth, C. Camilleri, H. Hofte, J. Plazinski, R. Birch, A. Cork, J. Glover, J. Redmond, and R. E. Williamson. 1998. Molecular analysis of cellulose biosynthesis in Arabidopsis. Science 279: 717-720.

Atanassova, R., N. Favet, F. Martz, B. Chabbert, M.-T. Tollier, B. Monties, B. Fritig, and M. Legrand. 1995. Altered lignin composition in transgenic tobacco expressing $O$ - methyltransferase sequences in sense and antisense orientation. Plant J. 8: 465-477.

Baker, R. J. 1986. Selection Indices in Plant Breeding. Boca Raton, FL: CRC Press

Baucher, M., B. Monties, M. Van Montagu, and W. Boerjan. 1998. Biosynthesis and genetic engineering of lignin. Crit. Rev. Plant Sci. 17: 125-197.

Baucher, M., M. A. Bernard-Vailhe, B. Chabbert, J.-M. Besler, C. Opsomer, M. Van Montagu, and J. Botterman. 1999. Down-regulation of cinnamyl alcohol dehydrogenase in transgenic alfalafa (Medicago sative L.) and the effect on lignin composition and digestibility. Plant Mol. Biol. 39:437-447.

Bernard Vailhé, M. A., J. M. Besle, M. P. Maillot, A. Cornu, C. Halpin, and M. Knight. 1998. Effect of downregulation of cinnamyl alcohol dehydrogenase on cell wall composition and on degradability of tobacco stems. J. Sci. Food. Agric. 76:505-514.

Bernard Vailhé, M. A., R. D. A. Cornu, M. P. Maillot, and J. M. Besle. 1996. Cell wall degradability of transgenic tobacco stems in relation to their chemical extraction and lignin quality. J. Agric. Food Chem. 44:11641169.

Bonin, C. P., I. Potter, G. F. Vanzin, and W-D. Reiter. 1997. The MURI gene of Arabidopsis thaliana encodes an isoform of GDP-D-mannose-4,6-dehydratase, catalyzing the first step in the de novo synthesis of GDPL-fucose. Proc. Natl. Acad. Sci. USA 94:2085-2090.

Brummer, E.C. 1998. Molecular and cellular technologies in forag improvement: an overview. p. 1-10.. In: Mo- lecular and Cellular Technologies for Forage Improvement. p.11-24. In: E.C. Brummer, N.S. Hill, C.A. Roberts (Eds.). CSSA Spec. Publ. 26. CSSA, Madison, WI.

Buendgen, M. R., J. G. Coors, A. W. Grombacher, and W. A. Russell. 1990. European corn borer resistance and cell wall composition of three maize populations. Crop Sci. 30:505-510.

Burn, J. E., T. Arioli, A. Betzner, R. Birch, A. Cork, and R. E. Williamson. 1998. Cellulose biosynthesis in Arabidopsis thaliana, molecular analysis and developmental effects of reduced synthesis. 8th Int. Cell Wall Mtg., Sept. 15, 1998, Norwich, UK, Abstr. 1.06.

Buxton, D. R. and M. D. Casler. 1993. Environmental and genetic effects on cell wall composition and digestibility. p. 685Sept. 714. In: H.G. Jung, D.R. Buxton, R.D. Hatfield, and J. Ralph (Eds.) Forage cell wall structure and digestibility. ASA. Madison, WI.

Buxton, D. R., and S. L. Fales. 1994. Plant environment and quality. p. 155-199. In: G. C. Fahey, Jr., M. Collins, D. R. Mertens, and L. E. Moser (Eds.). Forage Quality, Evaluation, and Utilization. ASA-CSSA-SSSA, Madison, WI, USA.

Casler, M. D. 1999a. Phenotypic recurrent selection methodology for reducing fiber concentration of smooth bromegrass. Crop Sci. 39:381-390.

Casler, M. D. 1999b. Structural responses to selection for reduced fiber concentration in smooth bromegrass. Crop Sci. 39:1435-1438.

Casler, M. D. 1999c. Correlated Responses in forage yield and nutritional value from phenotypic recurrent selection for reduced fiber concentration in smooth bromegrass. Theo. Appl. Genet. 99:1245-1254

Casler, M. D. and H. G. Jung. 1999. Selection and evaluation of smooth bromegrass clones with divergent lignin or etherified ferulic acid concentration. Crop Sci. 39:1866-1873

Casler, M. D., and K. P. Vogel. 1999. Accomplishments and impact from breeding for increased forage nutritional value. Crop Sci. 39:12-20.

Casler, M. D., D. R. Buxton, and K. P. Vogel. 2001. Genetic correlation between nutritive value and fitness of herbaceous plants. (in review).

Chapple, C. C. S., T. Vogt, B. E. Ellis, and C. R. Somerville. 1992. An Arabidopsis mutant defective in the general phenylpropanoid pathway. Plant Cell 4:1413-1424.

Cherney, J. H. 1990. Normal and brown-midrib mutations in relation to improved lignocellulose utilization. pp. 205214. In: D. E. Akin, L. G. Ljungdahl, J. R. Wilson, P. J. Harris (Eds.). Microbial and Plant Opportunities to Improve Lignocellulose Utilization by Ruminants, Elsevier, New York, USA.

Collins, M. and K. J. Moore. 1995. pp.147-161. In: R. F. Barnes, D. A. Miller, and C. J. Nelson (Eds). Forages II: The Science of Grassland Agriculture. Iowa State University Press, Ames, IA, USA.

Cornelius, D. R. and C. O. Johnston. 1941. Differences in plant type and reaction to rust among several collec- 
tions of Panicum virgatum L. J. Am. Soc. Agron. 33: $115-124$.

Conger, B. V. 1998. Genetic Transformation of Forage Grasses. p. 49-58. In: E. C. Brummer, N. S. Hill, and C. A. Roberts (Eds.). Molecular and Cellular Technologies for Forage Improvement. CSSA Special Publication Number 26.

Conger, B. V., Z. Tomaszewski, M. K. Odjakova, and H. Sun. 1999. Development of in vitro systems for switchgrass. Annual Report 1998 for Subcontract 11X-SY 161, Herbaceous Energy Crops Program, Environmental Sciences Division, Oak Ridge National Laboratory, Oak Ridge, TN.

Deetz, D. A., H. G. Jung, and D. R. Buxton. 1994. Waterdeficit effects on cell-wall composition and in vitro degradability of structural polysaccharides from alfalfa stems. Crop Sci. 36: 383-388.

Delmer, D. P. 1999. Cellulose biosynthesis: exciting times for a difficult field of study. Ann. Rev. Plant Physiol. Plant Mol. Biol. 50: 245-276.

Delmer, D. P., and B. A. Stone. 1988. Biosynthesis of plant cell walls. p. 373-420. In: J. Preiss (ed.). The Biochemistry of Plants, Vol. 14 Carbohydrates. Academic Press, Inc., San Deigo, CA.

Denchev, P. D. and B. V. Conger, 1994. Plant regeneration from callus culture of switchgrass. Crop Sci. 34:1623-1627.

de Ruiter, J. M. and Burns, J. C. 1987. Cell wall carbohydrates of flaccidgrass plant parts. III. Near infrared reflectance spectroscopy determination, rate, and extent of fermentation. Crop Sci. 27:1069-1076.

de Ruiter, J. M.; Burns, J. C.; McClure, W. F., and Timothy, D. H. 1988. Prediction of cell wall carbohydrates and quality in Panicum species by near infrared reflectance spectroscopy. Crop Sci. 28:348-353.

Dormann, P. and C. Benning. 1996. Functional expression of uridine 5'-diphospho-glucose 4-epimeras (EC 5.1.3.2) from Arabidopsis thaliana in Saccharomyces cerevisiae and Escherichia coli. Arch. Biochem. Biophys. 327: 27-34.

Dutta, G. S. and B. V. Conger. 1999. Somatic embryongenesis and plant regeneration from suspension cultures of switchgrass. Crop Sci. 39:243-247.

Duvick, Donald N. 1999. How much caution in the fields? Science. 286:418-419.

Dwivedi, U. N., W. H. Campbell, J. Yu, R. S. S. Datla, R. C. Bugos, V. L. Chiang, and G .K. Podila. 1994. Modification of lignin biosynthesis in transgenic Nicotiana through expression of an antisense $O$-methyltransferase gene from Populus. Plant Mol. Biol. 26: 61-71.

Eimert, K., P. Villand, A. Kilian, and L. A. Kleczkowski. 1996. Cloning and characterization of several cDNAs for UDP-glucose pyrophoshorylase from barley (Hordeum vulgare) tissues. Gene 170: 227-232.

Engels, F. M., and H. G. Jung. 1998. Alfalfa stem tissues: cell-wall development and lignification. Ann. Bot. 82: 561-568.

Falconer, D. S. 1981. Introduction to Quantitative Genetics, 2nd ed., Longman Inc., New York.
Fehr, W. R. and H. H. Hadley (Eds.) 1980. Hybridization of Crop Plants. Am. Soc. of Agron. Crop Sci. Soc. of Am., Madison, WI.

Frye, C.T. 1999. Non-native genotypes and outbreeding depresssion in plants: theoretical and impirical issues. p. 16. The Second Eastern Native Grass Symposium. November 17th to 19th, Baltimore, MD, Natural Resources Conservation Service, USDA.

Fritz, J. O., K. J. Moore, and K. P. Vogel. 1991. Ammonialabile bonds in high and low digestibility strains of switchgrass. Crop Sci. 31:1566-1570.

Gabrielsen, B. C., K. P. Vogel, B. E. Anderson, and J. K. Ward. 1990. Alkali-labile lignin phenolics and forage quality in three switchgrass strains selected for differing digestibility. Crop Sci. 30:1313-1320.

Godshalk, E. B., J. C. Burns, and D. H. Timothy. 1988a. Effectiveness of index selection for switchgrass forage yield and quality. Crop Sci. 28:825-830.

Godshalk, E. B., W. F. McClure, J. C. Burns, D. H. Timothy, and D. S. Fisher. 1988b. Heritability of cell wall carbohydrates in switchgrass. Crop Sci. 28:736-742.

Grabber, J. H., J. Ralph, R. D. Hatfield, and S. Quideau. 1997. $p$-Hydroxyphenyl, guaiacyl, and syringyl lignins have similar inhibitory effects on wall degradability. J. Agric. Food Chem. 45:2530-2532.

Grove, N. 1998. Quietly conserving nature. National Geographic Dec. 818-844.

Griffin, J. L., and G. A. Jung. 1983. Leaf and stem forage quality of big bluestem and switchgrass. Agron. J. 75: 723-726.

Gunter, L. E., G. A. Tuskan and S. D. Wullschleger. 1996. Diversity among populations of switchgrass based on RAPD markers. Crop Sci. 36:1017-1022.

Halim, R. A., D. R. Buxton, M. J. Hattendorf, and R. E. Carlson. 1989. Water-stress effects on alfalfa forage quality after adjustment for maturity differences. Agron. J. 81:189-194.

Hallauer, Arnel R. and J. B. Miranda. 1981. Quantitative Genetics in Maize Breeding. Iowa State University Press, Ames, IA.

Halpin, C., K. Holt, J. Chojecki, D. Oliver, B. Chabbert, B. Monties, K. Edwards, and G .A. Foxon. 1998. Maize brown-midrib (bm1) - a mutation affecting the cinnamyl alcohol dehydrogenase gene. Plant J. 14: 545-553.

Hatfield, R. D. 1993. Cell wall polysaccharide interactions and degradability. pp. 286-313. In: H. G. Jung, D. R. Buxton, R. D. Hatfield, and J. Ralph (Eds.). Cell Wall Structure and Digestibility. ASA-CSSA-SSSA, Madison, WI, USA.

Hatfield, R. D., H. G. Jung, J. Ralph, D. R. Buxton, and P. J. Weimer. 1994. A comparison of the insoluble residues produced by the Klason lignin and acid detergent lignin procedures. J. Sci. Food Agric. 65:51-58.

Hatfield, R. D., J. R. Wilson, and D. R. Mertens. 1999. Composition of cell walls isolated from cell types of grain sorghum stems. J. Sci. Food Agric. 79: 891899. 
Hibino, T., K. Takabe, T. Kawazu, D. Shibata, and T. Higuchi. 1995. Increase of cinnamaldehye groups in lignin of transgenic tobacco plants carrying an antisense gene for cinnamyl alcohol dehydrogenase. Biosci. Biotech. Biochem. 59: 929-931.

Hill, R. R., Jr. 1981. Selection for phosphorus and lignin content in alfalfa. $27^{\text {th }}$ Alfalfa Improvement Conference, Madison, WI, USA, July 8-10, 1980. Peoria, IL: USDA-ARS North Central Region.

Hopkins, A. A. 1993. Genetic Variation Among Switchgrasses for Agronomic, Forage Quality, and Biofuel Traits. Ph.D. Dissertation. University of NebraskaLincoln, Lincoln, NE. (Diss. Abstr. 1307730)

Hopkins, A. A., K. P. Vogel, and K. J. Moore. 1993. Predicted and realized gains from selection for in vitro dry matter digestibility and forage yield in switchgrass. Crop Sci. 253-258.

Hopkins, A. A., K. P. Vogel, K. J. Moore, K. D. Johnson, and I. T. Carlson. 1995a. Genotype effects and genotype by environment interactions for traits of elite switchgrass populations. Crop Sci. 35:125-132.

Hopkins, A. A., K. P. Vogel, K. J. Moore, K. D. Johnson, and I. T. Carlson. 1995b. Genetic variability and genotype $\mathrm{x}$ environment interactions among switchgrass accessions from the Midwestern USA. Crop Sci. 35:565571.

Hu, W-J., S. A. Harding, J. Lung, J. L. Popko, J. Ralph, D. D. Stokke, C-J. Tsai, and V. L. Chiang. 1999. Repression of lignin biosynthesis promotes cellulose accumulation and growth in transgenic trees. Nature Biotechnol. 17:808-812.

Hultquist, S. J., K. P. Vogel, D. J. Lee, K. Arumuganathan, and S. Kaeppler. 1996. Chloroplast DNA and nuclear DNA content variations among cultivars of switchgrass, Panicum virgatum L. Crop Sci.36:1049-1052.

Jung, H. G., M. D. Casler, W. Ni, and R. L. Phiilips. 1999a. Reduction of ferulate ester deposition and cross-linking improves cell wall digestibility of grasses. J. Dairy Sci. 82 (Suppl. 1):39-40.

Jung, H. G. and D. A. Deetz. 1993. Cell wall lignification and degradability. p. 315-346. In: H. G. Jung, D. R. Buxton, R. D. Hatfield, and J. Ralph (eds.). Forage Cell Wall Structure and Digestibility. ASA-CSSASSSA, Madison, WI, USA.

Jung, H. G., D. R. Mertens, and A. J. Payne. 1997a. Correlation of acid detergent lignin and Klason lignin with digestibility of forage dry matter and neutral detergent fiber. J. Dairy Sci. 80:1622-1628.

Jung, H. G. and W. Ni. 1998. Lignification of plant cell walls: impact of genetic manipulation. Proc. Natl. Acad. Sci. USA 95:12742-12743.

Jung, H. G., W. Ni., C. C. S. Chapple, and K. Meyer. 1999b. Impact of lignin composition on cell-wall degradability in an Arabidopsis mutant. J. Sci. Food Agric. 79: 922 928.

Jung, H. G., C. C. Sheaffer, D. K. Barnes, and J. L. Halgerson. 1997b. Forage quality variation in the U.S. alfalfa core collection. Crop Sci. 37:1361-1366.
Jung, H. G., V. H. Varel, P. J. Weimer, and J. Ralph. 1999c. Accuracy of Klason lignin and acid detergent lignin methods as assessed by bomb calorimetry. J. Agric. Food Chem. 47:2005-2008.

Jung, H. G. and K. P. Vogel. 1992. Lignification of switchgrass (Panicum virgatum L.) and big bluestem (Andropogon gerardii Vitman) plant parts during maturation and its effect on fibre degradability. J. Sci. Food Agric. 59:169-176.

Kalu, B. A. and G. W. Fick. 1983. Morphological stage of development as a predictor of alfalfa herbage quality. Crop Sci. 23:1167-1172.

Katsube, T., Y. Kazuta, H. Mori, K. Nakano, K. Tanizawa, and T. Fukui. 1990. UDP-glucose pyrophosphorylase from potato tuber: cDNA cloning and sequencing. $J$. Biochem. 108:321-326.

Keller, R. and J. Kossmann. 1998. Genetic modification of matrix polysaccharides. 8th Int. Cell Wall Mtg., Sept. 1-5 1998, Norwich, UK, Abstr. 1.04.

Kephart, K. D., D. R. Buxton, and R. R. Hill, Jr. 1989. Morphology of alfalfa divergently selected for herbage lignin concentration. Crop Sci. 29:778-782.

Kephart, K. D., D. R. Buxton, and R. R. Hill, Jr. 1990. Digestibility and cell wall components of alfalfa following selection for divergent herbage lignin concentration. Crop Sci. 30:207-212.

Kokubo, A., S. Kuraishi, and N. Sakurai. 1989. Culm strength of barley. Correlation among maximum bending stress, cell wall dimensions, and cellulose content. Plant Physiol. 91:876-882.

Kokubo, A., N. Sakurai, S. Kuraishi, and K. Takeda. 1991. Culm brittleness of barley (Hordeum vulgare L.) mutants is caused by smaller number of cellulose molecules in cell wall. Plant Physiol. 97:509-514.

Kondo, T., K. Mizuno, and T. Kato. 1987. Variation in solubilities of lignin in acid detergent and in alkali. $J$. Jpn. Grassl. Sci. 33:296-299.

Knapp, S. J. 1998. Marker-assisted selection as a strategy for increasing the probability of selection using superior genotypes. Crop Sci. 38:1164-1174.

Lee, D., K. Meyer, C. Chapple, and C. J. Douglas. 1997. Antisense suppression of 4-coumarate:coenzyme A ligase activity in Arabidopsis leads to altered lignin subunit composition. Plant Cell 9:1985-1998.

Li, L. G., Y. Osakabe, C. P. Joshi, and V. L. Chiang. 1999. Secondary xylem-specific expression of caffeoyl-coenzyme A 3-O-methyltransferase plays an important role in the methylation pathway associated with lignin biosynthesis in loblolly pine. Plant Mol. Biol. 40:555565.

Li, L., J. L. Popko, T. Umezawa, and V. L. Chiang. 2000. 5Hydroxyconiferyl aldehyde modulates enzymatic methylation for syringyl monolignol formation, a new view of monolignol biosynthesis in angiosperms. $J$. Biol. Chem. (in press).

Liu, B. H. 1998. Statistical Ggenomics: Linkage, Mapping, and QTL Analysis. CRC Press LLC, Boca Raton, Florida. 
Lowry, J. B., L. L. Conlan, A. C. Schlink, and C. S. McSweeney. 1994. Acid detergent dispersible lignin in tropical grasses. J. Sci. Food Agric. 65:41-49.

Lubberstedt, T., A. E. Melchinger, D. Klein, H. Degenhardt, and C. Paul. 1997. QTL mapping in testcrosses of European flint lines of maize. II. Comparison of different testers for forage quality traits. Crop Sci. 37:1913-1922.

MacKay, J. J., D. M. O’Malley, T. Presnell, F. L. Booker, M. M. Campbell, R. W. Whetten, and R. R. Sederoff. 1997. Inheritance, gene expression, and lignin characterization in a mutant pine deficient in cinnamoyl alcohol dehydrogenase. Proc. Natl. Acad. Sci. USA 94:8255-8260.

Mandebvu, P., J. W. West, G. M. Hill, R. N. Gates, R. D. Hatfield, B. G. Mullinix, A. H. Parks, and A. B. Caudle. 1999. Comparison of Tifton 85 and Coastal bermudagrass for yield, nutrient traits, intake, and digestion by growing beef steers. J. Anim. Sci. 77: 1572-1586.

Marten, G. C., J. S. Shenk, and F. E. Barton, (Eds.). 1989. Near Infrared Reflectance Spectroscopy (NIRS): Analysis of Forage Quality. USDA-ARS Agric Handbook. 643 (revised with supplements), 110 p. US Gov. Print. Off. Washington, D.C.,

Martinez-Reyna, J. M. and K. P. Vogel. 1998 Controlled hybridization technique for switchgrass. Crop Sci. 38:876-878.

McMillian, C. 1959. The role of ecotypic variation in the distribution of the central grassland of North America. Ecol. Mono. 29:285-308.

McMillian, C. 1965. Ecotypic differences within four North American prairie grasses. II. Behavorial variation within transplanted community fractions. Am. J. Bot. 52:55-65.

Mitchell, R. B., K. J. Moore, L. E. Moser, J. O. Fritz, and D. D. Redfern, 1997 Predicting developmental morphology in switchgrass and big bluestem. Agron. J .89:827832.

Mitchell, R. B., J. O. Fritz, K. J. Moore, L. E. Moser, K. P. Vogel, and D. D. Redfern, 2001. Predicting forage quality in switchgrass and big bluestem (in review).

Moore, K. J., L. E. Moser, K. P. Vogel, S. S. Waller, B. E. Johnson, and J. F. Pedersen. 1991. Describing and quantifying growth stages of perennial forage grasses. Agron. J. 83:1073-1077.

Moore, K. J., K. P. Vogel, A. A. Hopkins, J. F. Pedersen, and L. E. Moser. 1993. Improving the digestibility of warm-season perennial grasses. pp.447-448. Proc. XVII Int. Grassland Congress. New Zealand Grassland Society, NZ.

Morrison, I. M. 1980. Hemicellulosic contamination of acid detergent residues and their replacement by cellulosic residues in cell wall analysis. J. Sci. Food Agric. 31:639-645.

Moser, L. E. and K. P. Vogel. 1995. Switchgrass, big bluestem, and indiangrass. Chapter 32. p. 409-420. In: R. F. Barnes, D. A. Miller, and C. J. Nelson (Eds.).
Forages, 5th ed. Vol.I. An introduction to grassland agriculture. Iowa State Univ. Press, Ames, IA.

Myton, K. and S. C. Fry. 1994. Intraprotoplasmic feruloylation of arabinoxylans in Festuca arundinacea cell cultures. Planta 193:326-330.

Nelson, C. J. and J. J. Volenec. 1995. Environmental and physiological aspects of forage management. p.55-69. In: Robert F. Barnes, Darrell A. Miller, and C. Jerry Nelson (Eds.). Forages, 5th ed. Vol.I: An introduction to grassland agriculture. Iowa State Univ. Press, Ames, IA.

Neuffer, M. G., L. Jones, and M. S. Zuber. 1968. The Mutants of Maize. CSSA, Madison, WI, USA, pp. 74.

Newell, L. C. 1968. Effects of strain source and management practice on forage yields of two warm-season prairie grasses. Crop Sci. 8:205-210.

Ni, W., N. L. Paiva, and R. A. Dixon. 1994. Reduced lignin in trangenic plants containing a caffeic acid Omethytransferase antisense gene. Transgenic Res. 3:120-126.

Ni, W., R. L. Phillips, and H. G. Jung. 1997. Search for the gene(s) controlling ferulic acid cross-linking of lignin and polysaccharides in maize cell walls. Keystone Symp., Copper Mountain, CO, USA. p. 24.

Ni, W., R. L. Phillips, and H. G. Jung. 1998. Quantitative trait loci for cell-wall traits in maize. 8th Int. Cell Wall Mtg., November 1-5, 1998, Norwich, UK, Abstr. 1.38.

Osakabe, K., C. C. Tsao, L. G. Li, J. L. Popko, T. Umezawa, D. T. Carraway, R. H. Smeltzer, C. P. Joshi, and V. L. Chiang. 1999. Coniferyl aldehyde 5-hydroxylation and methylation direct syringyl lignin biosynthesis in angiosperms. Proc. Natl. Acad. Sci. USA 96:8955-8960.

Ostrander, B. M. and J. G Coors. 1997. Relationship between plant composition and European corn borer resistance in three maize populations. Crop Sci. 37:1741-1745.

Pear, J., Y. Kawagoe, W. Schreckengost, D. P. Delmer, and D. Stalker. 1996. Higher plants contain homologs of the bacterial CelA genes encoding the catalytic subunit of the cellulose synthase. Proc. Natl. Acad. Sci. USA 93:12637-12642.

Perrin, R. M., A. E. DeRocher, M. Bar-Peled, W. Zeng, L. Norambuena, A. Orellana, N. V. Raikhel, and K. Keegstra. 1999. Xyloglucan fucosyltransferase, an enzyme involved in plant cell wall biosynthesis. Science 284:1976-1979.

Piquemal, J., C. Lapierre, K. Myton, A. O'Connell, W. Schuch, J. Grima-Pettenati, and A.-M. Boudet. 1998. Down-regulation of cinnamyl-CoA reductase induces significant changes of lignin profiles in transgenic tobacco plants. Plant J. 13:71-83.

Potikha, T. and D. P. Delmer. 1995. A mutant of Arabidopsis thaliana displaying altered patterns of cellulose deposition. Plant J. 7:453-460.

Ralph, J., J. H. Grabber, and R. D. Hatfield. 1995. Ligninferulate cross-links in grasses: active incorporation of ferulate polysaccharide esters into ryegrass lignins. Carbohydrate Res. 275:167-178. 
Ralph, J., R. D. Hatfield, J. H. Grabber, H. G. Jung, S. Quideau, and R. F. Helm. 1998a. Cell wall crosslinking in grasses by ferulates and diferulates. pp. 209-236. In: N. G. Lewis and S. Sarkanen (Eds.). Lignin and Lignan Biosynthesis. ACS, Washington, DC.

Ralph, J., R. D. Hatfield, J. Piquemal, N. Yahiaoui, M. Pean, C. Lapierre, and A. M. Boudet. 1998b. NMR characterization of altered lignins extracted from tobacco plants down-regulated for lignification enzymes CAD and CCR. Proc. Natl. Acad. Sci. USA 95:12803-12808.

Ralph, J., J. J. MacKay, R. D. Hatfield, D. M. O'Malley, R. W. Whetten, and R. R. Sederoff. 1997. Abnormal lignin in a loblolly pine mutant. Science 277:235239.

Reiter, W-D. 1994. Structure, synthesis, and function of the plant cell wall. p. 955-988. In: E. M. Meyerowitz and C. R. Somerville (Eds.). Arabidopsis. Cold Spring Harbor Laboratory Press, Plainview, NY.

Reiter, W.-D., C. C. S. Chapple, and C. R. Somerville. 1993. Altered growth and cell walls in a fucose-deficient mutant of Arabidopsis. Science 261:1032-1035.

Risser, P. G. 1996. Summary. A new frame work for prairie conservation. pp.261-274. In: F. B. Sampson and F. L. Knoph (Eds.). Prairie Conservation. Preserving North America's most endangered ecosystem. Island Press, Washington, D.C.

Sampson, F. and F. Knopf. 1994. Prairie Conservation in North America. BioScience 44:418-421.

Sanderson, M.A. and Wolf, D.D. 1995. Switchgrass biomass composition during morphological developmment in diverse environments. Crop Sci. 35:1432-1438.

Saxena, I. M., F. C. Lin, and R. M. Brown, Jr. 1990. Cloning and sequencing of the cellulose synthase catalytic subunit gene of Acetobacter xylinium. Plant Mol. Biol. 15:673-683.

Service, R. F. 1998. Seed-sterilizing 'terminator technology' sows discord. Science 282:850-851.

Sewalt, V. J. H., J. W. Blount, and R. A. Dixon. 1996. Biotechnological improvement of alfalfa nutritive quality by anti-sense expression of COMT and CCOMT, methylating enzymes in lignin biosynthesis. North American Alfalfa Improv. Conf., Oklahoma City, Oklahoma, USA. p. 33.

Sewalt, V. J. H., W. Ni, J. W. Blount, H. G. Jung, S. A. Masoud, P. A. Howles, C. Lamb, and R. A. Dixon. 1997. Reduced lignin content and altered lignin composition in transgenic tobacco down-regulated in expression of $\mathbf{L}$-phenylalanine ammonia-lyase or cinnamate 4-hydroxylase. Plant Physiol. 115:41-50.

Shani, Z. and O. Shoseyov. 1999. Expression of cellulose binding domain (CBD) in transgenic plants increases biomass and polysaccharide biosynthesis. Impact of Molecular Biology on Crop Production and Crop Protection, Minneapolis, MN.

Shenk, J. S. and M. O. Westerhaus. 1994. The application of near infrared reflectance spectroscopy (NIRS) to forage analysis. p. 406-449. In: G. C. Fahey, Jr., M.
Collins, D. R. Mertens, and L. E. Moser (Eds.). Forage Quality, Evaluation, and Utilization. ASA-CSSASSSA, Madison, WI, USA.

Shenk, J. S. and M. O. Westerhaus. 1995. Forage analysis by near infrared spectroscopy. p. 111-120. In: R. F. Barnes, D. A. Miller, and C. J. Nelson (Eds.). Forages II: The Science of Grassland Agriculture. Iowa State University Press, Ames, IA, USA.

Shpigel, E., L. Roiz, R. Goren, and O. Shoseyov. 1998. Bacterial cellulose-binding domain modulates in vitro elongation of different plant cells. Plant Physiol. 117:1185-1194.

Sleper, D. A. 1987. Forage Grasses, pp.161-208. In: W.R. Fehr. (Ed.). Principles of Cultivar Improvement. Macmillian Publishing Co., New York.

Sleper, D. A. and C. Chen. 1998. Molecular mapping of forage grasses. In Molecular and Cellular Technologies for forage improvement. pp.11-24. In: E. C. Brummer, N. S. Hill, and C. A. Roberts (Eds.). CSSA Spec. Publ. 26. CSSA, Madison, WI

Steinauer, E. M. and S. L.Collins. 1996. Prairie ecology The tallgrass prairie. pp. 40-52. In: F. B. Sampson and F. L. Knoph (Eds.). Prairie Conservation. Preserving North America's Most Endangered Ecosystem. Island Press, Washington, D.C.

Stewart, D., N. Yahiaouti, G. J. McDougall, K. Myton, C. Marque, A. M. Boudet, and J. Haigh. 1997. Fouriertransform infrared and Raman spectroscopic evidence for the incorporation of cinnamaldehydes into the lignin of transgenic tobacco (Nicotiana tabacum L.) plants with reduced expression of cinnamyl alcohol dehydrogenase. Planta 201:311-318.

Stuber, C. W., M. Polacco, and M. L. Senior. 1999. Synergy of empirical breeding, marker-assisted selection, and genomics to increase crop yield potential. Crop Sci. 39:1571-1583.

Surprenant, J., D. K.Barnes, R. H. Busch, and G. C. Marten. 1988. Bidirectional selection for neutral detergent fiber and yield in reed canarygrass. Can. J. Plant Sci. 68:705-712.

Tamagnone, L., A. Merida, A. Parr, S. Mackay, F. A. CulianezMacia, K. Roberts, and C. Martin. 1998. The AmMYB308 and AmMYB330 transcription factors from Antirrhinum regulate phenylpropaniod and lignin biosynthesis in transgenic tobacco. Plant Cell 10:135-154.

Taylor, N., P. Poindexter, W. Schneible, S. Cutler, C. Somerville, and S. Turner. 1998. Molecular characterization of irx3, a mutant deficient in cellulose deposition. 8th Int. Cell Wall Mtg., Sept. 1-5, 1998, Norwich, UK, Abstr. 1.53

Taylor, N. G., W. R. Scheible, S. Cutler, C. R. Somerville, and S. R. Turner. 1999. The irregular xylem3 locus of Arabidopsis encodes a cellulase synthase required for secondary wall synthesis. Plant Cell 11:769-780.

Tenhaken, R. and O. Thulke. 1996. Cloning of an enzyme that synthesizes a key nucleotide-sugar precursor of hemicellulose biosynthesis from soybean: UDP-glucose dehydrogenase. Plant Physiol. 112:1127-1134. 
Theander, O., P. Aman, E. Westerlund, R. Andersson, and D. Pettersson. 1995. Total dietary fiber determined as neutral sugar residues, uronic acid residues, and Klason lignin (The Uppsala Method): collaborative study. $J$. AOAC Int. 78: 1030-1044.

Turner, S. R., and C. R. Somerville. 1997. Collapsed xylem phenotype of Arabidopsis identifies mutants deficient in cellulose deposition in the secondary wall. The Plant Cell 9:689-701.

Van Soest, P. J. 1994. Nutritional Ecology of the Ruminant, 2nd ed., Cornell University, Ithaca, NY, pp. 476 .

Vignols, F., J. Rigau, M. A. Torres, M. Capellades, and P. Puigdomenech. 1995. The brown midrib (bm3) mutation in maize occurs in the gene encoding caffeic acid $O$-methyltransferase. Plant Cell 7:407-416.

Vogel, K. P., H. J. Gorz, and F. A. Haskins. 1981. Divergent selection for in vitro dry matter digestibility in switchgrass. Crop Sci. 21:39-41.

Vogel, K. P., F. A. Haskins, H. J. Gorz, B. A. Anderson, and J. K. Ward. 1991. Registration of 'Trailblazer' switchgrass. Crop Sci. 31:1388.

Vogel, K.P. and K.J. Moore. 1993. Native North American Grasses. pp. 284-293. In: J. Janick and J. E. Simon (Eds.). New Crops. Proc 2nd. Nat. Symp. New Crops. Indianapolis, IN. Oct. 6-9, 1991. John Wiley \& Sons, Inc. New York.

Vogel, K. P. and J. F. Pedersen. 1993. Breeding systems for cross-pollinated perennial grasses. Plant Breeding Rev. 11:251-274.

Vogel, K. P. and D. A. Sleper. 1994. Alteration of plants via genetics and plant breeding. p. 891-921. In: G. C. Fahey, Jr., M. Collins, D. R. Mertens, and L. E. Moser (Eds.). Forage Quality, Evaluation, and Utilization. ASA-CSSA-SSSA, Madison, WI, USA.
Vogel, K. P., A. A. Hopkins, K. J. Moore, K. D. Johnson, and I. T. Carlson. 1996. Registration of 'Shawnee' switchgrass. Crop Sci. 36:1713.

USDA-ARS. 1999. Fact Sheet- Why USDA's Technology Protection System (aka 'Terminator') Benefits Agriculture. Internet site:http://www.ars.usda.gov/misc/ fact.htm.

United States Patent Office. 1999. United States Patent Number 5,723,765: Control of gene expression, issued on March 3, 1998 to Delta and Pine Land C. and the United States Department of Agriculture. Inventors: M. J. Oliver, J. E. Quisenberry, N. L. G Trolinder, and D. L. Keim.

Ward, M. G., J. K. Ward, B. E. Anderson, and K. P. Vogel. 1989. Grazing selectivity and in vivo digestibility of switchgrass strains selected for differing digestibility. J. Anim. Sci. 67:1418-1424.

Wilson, J. R. 1993. Organization of forage plant tissues. pp. 1-32. In: H. G. Jung, D. R. Buxton, R. D. Hatfield, and J. Ralph (Eds.). Forage Cell Wall Structure and Digestibility. ASA-CSSA-SSSA, Madison, WI, USA.

Wilson, J. R., B. Deinum, and F. M. Engels. 1991. Temperature effects on anatomy and digestibility of leaf and stem of tropical and temperate forage species. Neth. J. Agric. Sci. 39:31-48.

Wricke, G. and W. E. Weber. 1986. Quantitive Genetics and Selection in Plant Breeding. Berlin, New York: Walter de Gruyter

Yahiaoui, N., C. Marque, K. E. Myton, J. Negrel, and A. M. Boudet. 1998. Impact of different levels of cinnamyl alcohol dehydrogenase down-regulation on lignins of transgenic tobacco plants. Planta 204: 8-15.

Ye, X., S. Al-Babili, A. Klöti, J. Zhang, P. Lucca, P. Beyer, and I. Potrykus. 2000. Engineering the provitamin A ( $\beta$-carotene) biosynthetic pathway into (carotenoid free) rice endosperm. Science 287:303-306. 